DEMOGRAPHIC RESEARCH

VOLUME 39, ARTICLE 44, PAGES 1181-1226

PUBLISHED 11 DECEMBER 2018

https://www.demographic-research.org/Volumes/Vol39/44/

DOI: 10.4054/DemRes.2018.39.44

Research Article

Contemporary female migration in Ghana:

Analyses of the 2000 and 2010 Censuses

Samantha R. Lattof

Ernestina Coast

Tiziana Leone

Philomena Nyarko

(C) 2018 Lattof, Coast, Leone \& Nyarko.

This open-access work is published under the terms of the Creative Commons Attribution 3.0 Germany (CC BY 3.0 DE), which permits use, reproduction, and distribution in any medium, provided the original author(s) and source are given credit.

See https://creativecommons.org/licenses/by/3.0/de/legalcode. 


\section{Contents}

1 Introduction 1182

2 Background 1183

$2.1 \quad$ Migration in Ghana 1183

$2.2 \quad$ Gender and migration $\quad 1185$

2.3 Data sources for analysing migration in Ghana 1187

$3 \quad$ Data and methods $\quad 1188$

3.1 Data 1188

$\begin{array}{lll}3.2 & \text { Methods } & 1191\end{array}$

$4 \quad$ Results 1192

4.1 Identification of migrants 1192

4.2 Demographic structure of internal migrants 1196

$\begin{array}{ll}4.3 & \text { Interregional female migration } \\ \end{array}$

5 Discussion 1203

6 Acknowledgements 1206

$\begin{array}{ll}\text { References } & 1207\end{array}$

$\begin{array}{ll}\text { Appendices } & 1212\end{array}$ 


\title{
Contemporary female migration in Ghana: Analyses of the 2000 and 2010 Censuses
}

\author{
Samantha R. Lattof ${ }^{1}$ \\ Ernestina Coast ${ }^{2}$ \\ Tiziana Leone ${ }^{3}$ \\ Philomena Nyarko ${ }^{4}$
}

\begin{abstract}
BACKGROUND

Knowledge of female migration patterns is scant despite increased recognition and reporting of the feminization of migration. Recent data on female internal migration in Ghana challenges historical assumptions that underestimated female migration.
\end{abstract}

\section{OBJECTIVE}

This study presents the first detailed comparative analyses of female migration using microdata from Ghana's censuses (2000 and 2010) and exploits this national data to understand the gendered dimensions of migration.

\section{METHODS}

Secondary analyses use direct and indirect methods to describe the scale, type, and demographic structure of contemporary female migration; assess the distribution of female migrants across age and geography; and estimate net internal female migration.

\section{RESULTS}

Excluding international migrants, census microdata identified $31.1 \%$ of females as internal migrants in 2000 and $37.4 \%$ of females as internal migrants in 2010 . Workingage migration was particularly pronounced in 2010, reinforcing economic opportunity as a likely driver of migration for both sexes. Female migrants were significantly more likely than female nonmigrants to reside in urban areas and work for pay, profit, or family gain. By 2010, married women were less likely to migrate than peers who had

\footnotetext{
${ }^{1}$ London School of Economics and Political Science, London, UK. Email: lattof@post.harvard.edu.

${ }^{2}$ London School of Economics and Political Science, London, UK.

${ }^{3}$ London School of Economics and Political Science, London, UK.

${ }^{4}$ University of Ghana, Legon and Ghana Statistical Service, Accra, Ghana.
} 
never married. Net out-migration exceeded net in-migration in eight of Ghana's ten regions.

\section{CONTRIBUTION}

Our analyses expand the evidence base on contemporary female migration and refute the outdated stereotype that girls and women do not participate in migration. The prominence of the Greater Accra and Ashanti Regions as destinations for female migrants suggests that interventions are needed in Ghana's more rural regions to reduce poverty and develop greater economic opportunities for girls and women.

\section{Introduction}

Due to population growth and urbanization, projections suggest that two-thirds of the world's population will reside in urban areas by 2050 , with most of this increase occurring in Asia and Africa (UNDESA 2014). Planning for and managing this changing population distribution will require better understanding of new migration patterns and the impacts of internal migration. This includes a better understanding of female migration, which has been historically underestimated, with analyses focused on male migrants or assumptions that migrants were male (Caldwell 1969; Zlotnik 1995).

Knowledge of female migration patterns is scant despite increased recognition and reporting of the feminization of internal migration (Hofmann and Buckley 2012; Beegle and Poulin 2013). Research from South Africa challenges the assumption that females represent the residentially stable population, finding women in rural areas to be highly mobile (Camlin, Snow, and Hosegood 2014). In Malawi, where young women now migrate more than young men, assumptions of traditional patterns of matrilocal residence following marriage no longer hold (Beegle and Poulin 2013). As evidence reveals changes in the sex composition of migrants, it also reveals changes in the reasons for migrating.

While both sexes may attribute their migration decisions to factors such as the need to seek employment or a lack of independence at the place of origin, genderspecific factors emerge. In South Africa, girls experience an increased risk of moving out of the household following a parent's AIDS-related death compared to boys; families experiencing a death may expect girls to perform caring duties elsewhere or may prefer to keep boys (Ford and Hosegood 2005). In Ghana, girls and women attribute their migrations to the need to accumulate property for marriage; to avoid harm, including female genital mutilation; and to avoid forced or arranged marriages 
that may be polygamous (Anarfi and Agyei 2009). ${ }^{5}$ These factors influence both the decision to migrate and the choice of destination.

Data from Ghana's two most recent Population and Housing Censuses (2000 and 2010) indicates that there are more female than male internal migrants, particularly at younger ages (GSS 2013c). The growing number of younger migrants puts increasing pressure on social services and employment opportunities in urban areas. Some migrants move to Ghana's urban areas independent of available resources or employment opportunities (Agyei and Ofosu-Mensah Ababio 2009).

This study analyses Ghana's 2000 and 2010 Censuses using census microdata disaggregated by sex to provide a comprehensive picture of internal female migration at all ages. We use direct and indirect techniques to analyse the patterns, trends, and determinants of contemporary female migration. Our comparative analyses are the first to exploit national data from the 2000 and 2010 Censuses with a view to understanding the gendered dimensions of migration in Ghana.

\section{Background}

\subsection{Migration in Ghana}

Migration has historically been a way of life in West Africa and migration within Ghana is no exception. Ghana's internal migration is primarily a north-south phenomenon established well before the census started officially recording migration data in 1960 (Agyei and Ofosu-Mensah Ababio 2009). Since 1960, each census has recorded large out-migration streams from Ghana's northern regions and significant inmigration streams into the Greater Accra Region, with Ghana's 2010 Census recording an intercensal in-migration rate of $40.72 \%$ for Greater Accra (GSS 2013c). Nearly onethird (32.2\%) of the Greater Accra Region's population is between the ages of 15 and 29 years, due to a high rate of age-selective in-migration and rapid natural increase (GSS 2013b). Migrants residing in Accra also tend to be long-term migrants, with only about one in ten having moved in the 12 months prior to the 2010 Census (GSS 2013b). As a result, Ghana's urban centres (Figure 1) are facing growing challenges brought on by unemployment, inadequate sanitation, and the development of shanty towns. Of the 1.6 million migrants residing in the Greater Accra Region during the 2010 Census, about $10 \%$ originated from Ghana's three northern regions (GSS 2013b).

With growing social acceptance of female independence and mobility, girls and women are now the majority of Ghana's internal migrants. Among adolescents, females

\footnotetext{
${ }^{5}$ Polygamy is illegal under Ghanaian civil law, but it is common in northern Ghana.
} 
migrate from Ghana's rural areas to the country's urban areas at greater rates than males (GSS 2013a). The same pattern exists among youth aged 25 years and younger, with girls and young women comprising $60.5 \%$ of migrant youth (Anarfi and Appiah 2009). Girls frequently migrate before completing their education. Depending on the estimates, between $50 \%$ and $80 \%$ of female migrants have no formal education (Agyei and OfosuMensah Ababio 2009; Frempong-Ainguah, Badasu, and Codjoe 2009; Quartey and Yambilla 2009).

Figure 1: Map of Ghana by region with differentiated urbanization levels (2010)

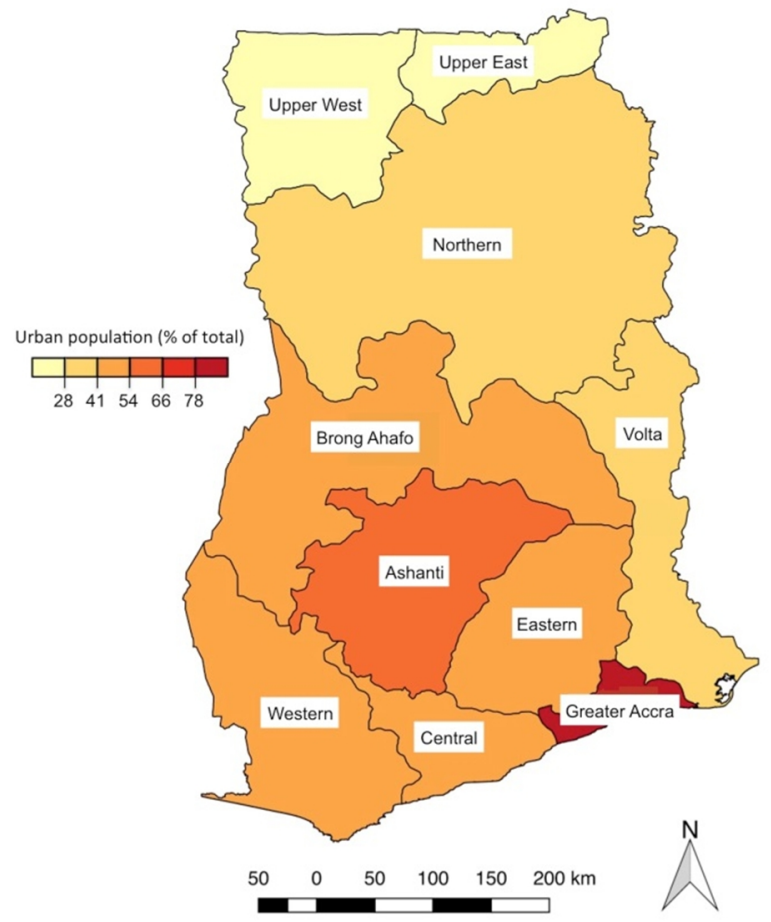

Note: Map created by the authors.

There is debate about whether independent child migrants decide to migrate primarily as a result of poverty or for economic reasons (Anarfi and Agyei 2009). Commonly cited causes of child migration include deteriorating agricultural land, drought, poor market facilities, poor transport networks, lack of employment 
opportunities, and lack of desire to participate in the agricultural industry (FrempongAinguah, Badasu, and Codjoe 2009). Urban-pull factors and rural-push factors also influence children's migration decisions. Push factors for child migration include parental inability to cater for their children's needs, ethnic conflicts, lack of privacy and money, lack of interest in schooling from parents and/or children, maltreatment by family members, desire to prevent being given away in marriage, and lack of independence (Frempong-Ainguah, Badasu, and Codjoe 2009). Pull factors for child migration include assisting a sibling with work, schooling, learning a trade, working for money, experiencing city life, and staying with a relative (Frempong-Ainguah, Badasu, and Codjoe 2009).

Child migrants experience a number of problems related to either their work or their young age: for instance, a decline in business, cheap prices for migrant services, harassment from city guards, financial problems, physically demanding work, work that is too difficult, no/insufficient work, no place to sleep, and high taxes (Kwankye and Addoquaye Tagoe 2009). Given these challenges, child migrants frequently return to their place of origin (Addoquaye Tagoe and Kwankye 2009). A survey conducted in northern Ghana among returned child migrants found that other reasons for children's return included continuing their education, changed marital status, and being needed at home (Addoquaye Tagoe and Kwankye 2009). As children (and their families) appear to constantly weigh the costs and benefits of migrating to and from their place of origin, repeated migrations may occur (Anarfi and Kwankye 2009).

\subsection{Gender and migration}

Defining the roles of girls and women as daughters, wives, and mothers has failed to recognize women's work beyond reproductive labour (e.g., caregiving, household labour, unpaid work). This narrow view of female roles is present in the literature on migration. Migrant girls and women may be classified as 'dependent' or 'independent' based on whether they migrate as daughters and wives or as members of the workforce (Llácer et al. 2007: ii4). Similarly, the migration literature has referred to girls and women who migrate with fathers and husbands as "passive" rather than "active" migrants (Findley 1989). These labels are absent from the literature on migrant boys and men. Male migrants are not classified according to their relationship to their mothers and wives.

In addition to using different language to describe the migration of girls and women, the migration literature has historically overlooked the roles of female migrants. Girls' and women's forms of migration and their migration-related employment have often been invisible and unrecognised, especially with regards to 
migrant domestic work (Elias 2010). This invisibility stems from research in the 1960s and 1970s in which researchers often assumed migrants were male, focusing analyses on male migrants and historically underestimating female migration (Caldwell 1969; Zlotnik 1995). Sex-disaggregated census data increasingly shows growing mobility among girls and women, with migration rates frequently balanced between the sexes (Beegle and Poulin 2013; GSS 2013c; Camlin, Snow, and Hosegood 2014). While census data is limited to sex-disaggregated analyses, examining differences between the migration patterns of women and men is the first step in advancing our understanding of gender and migration.

Migration increasingly allows girls and women to challenge traditional social roles in rural societies (Guo, Chow, and Palinkas 2011). In Ghana, girls challenge these roles by independently deciding to migrate ( $70 \%$ of girls vs. $54 \%$ of boys) and by personally financing their migrations (57.6\% of girls vs. 34.9\% of boys) (Anarfi and Agyei 2009). Research from the Democratic Republic of Congo and Senegal finds that, in patriarchal settings, women's access to and support from migrant networks is crucial in order for women to migrate (Toma and Vause 2014). Upon migrating, migrant women develop and strengthen community ties by strategically giving gifts, sharing food, caring for children, and participating in reciprocal labour (Tufuor et al. 2015).

Evidence suggests that gender-specific factors may influence girls' and women's choice of destination. Based on a survey of 450 child migrants residing in Accra and Kumasi in 2005, researchers found that migrant girls were occasionally pursued and recaptured by their families; this finding may illustrate one of the reasons why many females decide to move to Accra, the urban centre that is furthest from the northern regions (Anarfi and Agyei 2009). In addition to choice of destination, gender may influence where migrants work. In Accra, public spaces have historically been gendered: markets are associated with female entrepreneurship, whereas bus stations are associated with male entrepreneurship (Thiel and Stasik 2016).

When mothers migrate, it can lead to restructuring of the parent-child relationship as well as paradoxes pertaining to mothers' caregiving role (Resurreccion 2009; Contreras and Griffith 2012). With economic support now a key component of 'superior motherhood,' this type of support comes at a cost for migrant mothers: mothers may be absent from their children's lives and unable to provide their children with emotional support and care from afar (Contreras and Griffith 2012: 62). Migration can enhance the value of motherhood, as mothers provide increased resources and improved material conditions for their children; however, migration can also diminish motherhood, as other family members are called upon to provide childcare responsibilities in the mother's absence (Contreras and Griffith 2012). In this regard, mothers migrating independently without their children are in fact dependent upon family members' ability to fulfil the daily caregiving role. 


\subsection{Data sources for analysing migration in Ghana}

Ghana's internal migration data comes primarily from the decennial censuses and ad hoc population surveys, as Ghana has no population register or administrative data suitable for migration analyses. While census data provides limited depth of information on female migration, it provides the most comprehensive source of evidence on female migration at all ages that can be exploited using demographic techniques. Ad hoc subnational surveys and research on female migration in Ghana are localized and small-scale, precluding national-level analyses (Awumbila and ArdayfioSchandorf 2008; Anarfi and Kwankye 2009). These studies address important aspects of migration, such as push- and pull-factors underlying independent child migration, childcare practices among young migrants, and migrants' livelihood strategies. National migration data comes from the Ghana Migration Study (1991-1992), "Development on the Move" migration study (2008-2009), Ghana Demographic and Health Surveys (conducted in 1988, 1993, 1998, 2003, 2008, and 2014), Ghana Living Standards Survey (conducted in 1987, 1988, 1991-1992, 1998-1999, 2005-2006, and 2013), and post-independence censuses (1960, 1970, 1984, 2000 and 2010). Each of these data sources has strengths and limitations for national-level analyses of migration.

The 1991-1992 Ghana Migration Study (GMS), developed in response to inadequate migration data in prior censuses, provided a depth of migration data unparalleled by more recent surveys. It collected evidence on the processes, mechanisms, and effects of internal migration; however, this survey has not been repeated (Twum-Baah, Nabila, and Aryee 1995). Despite its relative depth of migration data, the 1991-1992 GMS has significant limitations: exclusion of child migrants younger than 15 years of age; documented implementation challenges, such as inaccessible enumeration areas (i.e., resulting from floods, ethnic conflicts, and broken transportation); and lack of technical assistance required to implement the survey (Twum-Baah, Nabila, and Aryee 1995).

To fill evidence gaps in migration's developmental impacts and policy that were unaddressed in the GMS, the Regional Institute for Population Studies at the University of Ghana and the Global Development Network collaborated in 2008-2009 on a nationally representative survey entitled "Development on the Move: Measuring and Optimising Migration's Economic and Social Impacts" (Yeboah et al. 2010). This study focused on international migration and its socioeconomic impacts on households and individuals remaining in Ghana.

Ghana's Demographic and Health Surveys (GDHS) (1988, 1998, 2003, and 2008) have each asked the same single question about migration - "How long have you been living continuously in (NAME OF CURRENT PLACE OF RESIDENCE)?" - and defined migrants based on how long they have lived in the enumeration area (GSS and IRD 1989; GSS and Macro International 1999; GSS, NMIMR, and ICF Macro 2004 
2009). This question has several drawbacks for measuring migration. It precludes identification of types of migrants (e.g., internal, international) and calculation of subnational interregional migration flows. The 1993 GDHS included a five-question migration module that went beyond birthplace to include whether or not the respondent had lived elsewhere for at least six months, age at first migration, and reason for first migration (GSS, GHS, and ICF Macro 1994). Most recently, the 2014 GDHS asked respondents how many times in the last 12 months they had been away from home for one or more nights and whether they had been away from home for more than one month at a time (GSS, GHS, and DHS Program 2015). These questions have not been repeated, preventing comparative analyses across GDHS. Furthermore, GDHS sampling in Ghana excludes girls and women outside 15-49 years of age.

The Ghana Living Standards Survey (GLSS) assesses living conditions in Ghanaian households using a nationally representative sample. In the household roster, the 2012-2013 GLSS6 captures region/country of birth (question 11) and how many months during the past 12 months the person (aged six months and older) has been away from this household (question 22). The survey also contains a ten-question module on migration (Section 5A) that collects data such as timing of move/return, intentions to stay, occupation and industry of migrant labour, and reason for migrating. The GLSS6 is a valuable source of migration data since this migration data is linked to detailed individual- and household-level sociodemographic data; however, the tenquestion module is asked only of household members aged seven years or older.

\section{Data and methods}

\subsection{Data}

Through the Ghana Statistical Service (GSS), we obtained a 10\% random sample for both the 2000 and 2010 Censuses along with all available questionnaires, manuals, codebooks, and reports. To assess data quality, we reviewed the post-enumeration surveys conducted to assess coverage and content errors (GSS 2003, 2012). Three months after the 2000 Census, the post-enumeration survey sampled 200 out of 26,716 enumeration areas to collect data on eight selected census questions, including place of usual residence (GSS 2003). The post-enumeration survey data was matched to the census data and reconciled where necessary. Unfortunately, planning for the 2000 postenumeration survey was more effective than its data management; the 2000 postenumeration survey data is physically missing, preventing analysis of whether or not the final census results required adjustment. 
Implementation was greatly improved for the 2010 Census post-enumeration survey, which sampled 250 out of 37,488 enumeration areas seven months after the census (GSS 2012). The post-enumeration survey found an omission rate of $3 \%$, the erroneous inclusion of $1.3 \%$ of the population in the census, and a greater chance of males (3.3\%) being omitted from the census than females (2.8\%) (GSS 2012). Based on the low net coverage error of $1.8 \%$ at the national level, it was unnecessary to adjust the 2010 Census results for our analyses. However, some populations, such as migrant kayayei (female porters who carry loads on their heads at markets and transportation centres), proved challenging to enumerate in the 2010 Census since they are highly mobile and occasionally homeless; this population reportedly exceeded estimates and required additional time to enumerate in Accra (Daily Express 2010). Comparing key variables between the microdata and censuses reveals that the microdata sample from the 2010 Census more accurately reflects the complete census than the microdata sample from 2000, in which the age structure differs slightly (Table 1).

Table 1: Comparison of microdata samples to the 2000 and 2010 Censuses

\begin{tabular}{|c|c|c|c|c|}
\hline & \multicolumn{2}{|c|}{2000} & \multicolumn{2}{|c|}{2010} \\
\hline & Census & Sample (10.0\%) & Census & Sample (10.0\%) \\
\hline Total population & $18,912,079$ & $1,891,158$ & $24,658,823$ & $2,466,289$ \\
\hline \multicolumn{5}{|l|}{ Sex } \\
\hline Female & $9,554,697(50.5 \%)$ & $955,504(50.5 \%)$ & $12,633,978(51.2 \%)$ & $1,262,598(51.2 \%)$ \\
\hline Male & $9,357,382(49.5 \%)$ & $935,654(49.5 \%)$ & $12,024,845(48.8 \%)$ & 1,203,691 (48.8\%) \\
\hline \multicolumn{5}{|l|}{ Enumeration locality } \\
\hline Rural & $10,637,809(56.2 \%)$ & $1,063,732(56.2 \%)$ & $49.1 \%$ & $49.1 \%$ \\
\hline Urban & $8,274,270(43.8 \%)$ & 827,426 (43.8\%) & $50.9 \%$ & $50.9 \%$ \\
\hline \multicolumn{5}{|l|}{ Age structure } \\
\hline Median age & 19.4 & 19.0 & 20.0 & 20.0 \\
\hline Dependent population $\dagger$ & $8,965,233(47.4 \%)$ & $880,031(46.6 \%)$ & $10,617,930(43.1 \%)$ & $1,060,608(43.0 \%)$ \\
\hline \multicolumn{5}{|c|}{ Regional population distribution } \\
\hline Highest share & Ashanti (19.1\%) & Ashanti (19.1\%) & Ashanti (19.4\%) & Ashanti (19.3\%) \\
\hline Lowest share & Upper West (3.0\%) & Upper West (3.0\%) & Upper West $(2.8 \%)$ & Upper West $(2.9 \%)$ \\
\hline
\end{tabular}

Note: $\uparrow$ Respondents aged $<15$ and $>64$ years.

The 2000 and 2010 Censuses both included four questions to measure migration. However, the phrasing of these questions differed (Table 2), affecting cross-census comparability. Given these changes to the phrasing of migration questions between the 2000 and 2010 Censuses, the 2010 Census National Analytical Report acknowledges that the census data underestimates people's actual mobility and does "not provide enough and adequate information on patterns and differentials of migration in a country" (GSS 2013c: 205). Several response categories also changed between the 2000 
and 2010 Censuses. Changes to response categories between censuses (e.g., additions, removals, or changes in definitions), and their analytic implications, are explored in the results.

\section{Table 2: Criteria for classifying migrants and nonmigrants by Ghana census questions on migration}

\begin{tabular}{|c|c|c|c|c|c|}
\hline $\begin{array}{l}2000 \text { Census } \\
\text { Census question }\end{array}$ & $\begin{array}{l}\text { Migrant } \\
\text { determination }\end{array}$ & Nonmigrant & $\begin{array}{l}2010 \text { Census } \\
\text { Census question }\end{array}$ & $\begin{array}{l}\text { Migrant } \\
\text { determination }\end{array}$ & Nonmigrant \\
\hline $\begin{array}{l}\text { P06a BORN IN } \\
\text { THIS } \\
\text { TOWN/VILLAGE: } \\
\text { Was (NAME) born in } \\
\text { this town or village? } \\
\text { If Yes go to P07. } \\
\text { [Note: Only asked of } \\
\text { respondents who } \\
\text { were Ghanaian by } \\
\text { birth.] }\end{array}$ & $\begin{array}{l}\text { Person who is Ghanaian by } \\
\text { birth and enumerated in a place } \\
\text { different from the place where } \\
\text { s/he was born } \\
\text { A NO answer is a lifetime } \\
\text { migrant. } \\
\text { International migrant = person } \\
\text { for whom this answer is missing } \\
\text { (implying that they are a foreign } \\
\text { citizen) }\end{array}$ & $\begin{array}{l}\text { Person who is } \\
\text { Ghanaian by } \\
\text { birth and } \\
\text { enumerated in } \\
\text { the place } \\
\text { where s/he } \\
\text { was born } \\
\text { A YES answer } \\
\text { is a } \\
\text { nonmigrant. }\end{array}$ & $\begin{array}{l}\text { P05 BIRTHPLACE: } \\
\text { Was (NAME) born } \\
\text { in this town/village? } \\
\text { If Yes, go to P07. }\end{array}$ & $\begin{array}{l}\text { Person enumerated in } \\
\text { a place different from } \\
\text { the place where s/he } \\
\text { was born } \\
\text { A NO answer is a } \\
\text { migrant. }\end{array}$ & $\begin{array}{l}\text { Person } \\
\text { enumerated } \\
\text { in the place } \\
\text { where s/he } \\
\text { was born } \\
\text { A YES } \\
\text { answer is a } \\
\text { nonmigrant. }\end{array}$ \\
\hline $\begin{array}{l}\text { P06b BIRTHPLACE } \\
\text { OUTSIDE THIS } \\
\text { TOWN/VILLAGE: In } \\
\text { what region or } \\
\text { country was (NAME) } \\
\text { born? } \\
\text { [Note: Only asked of } \\
\text { respondents who } \\
\text { were Ghanaian by } \\
\text { birth.] }\end{array}$ & $\begin{array}{l}\text { Person who is Ghanaian by } \\
\text { birth and enumerated in a place } \\
\text { different from the place where } \\
\text { s/he was born } \\
\text { Internal migrant = person who is } \\
\text { Ghanaian by birth and born in } \\
\text { one of Ghana's nine regions } \\
\text { outside the region of } \\
\text { enumeration } \\
\text { International migrant = person } \\
\text { who is Ghanaian by birth and } \\
\text { born outside Ghana } \\
\text { All respondents answering are } \\
\text { lifetime migrants. }\end{array}$ & - & $\begin{array}{l}\text { P06 BIRTHPLACE: } \\
\text { In what region or } \\
\text { country was } \\
\text { (NAME) born? }\end{array}$ & $\begin{array}{l}\text { Person enumerated in } \\
\text { a place different from } \\
\text { the place where s/he } \\
\text { was born } \\
\text { Internal migrant = } \\
\text { person born in Ghana } \\
\text { outside the place of } \\
\text { enumeration } \\
\text { International migrant }= \\
\text { person born outside } \\
\text { Ghana } \\
\text { All respondents are } \\
\text { migrants. }\end{array}$ & - \\
\hline $\begin{array}{l}\text { P07 USUAL PLACE } \\
\text { OF RESIDENCE: In } \\
\text { what district is } \\
\text { (NAME'S) usual } \\
\text { residence? }\end{array}$ & $\begin{array}{l}\text { Person enumerated in a place } \\
\text { different from her/his usual } \\
\text { place of residence } \\
\text { Internal migrant = person who } \\
\text { usually resides in one of } \\
\text { Ghana's districts outside the } \\
\text { district of enumeration } \\
\text { International migrant = person } \\
\text { who usually resides outside } \\
\text { Ghana }\end{array}$ & $\begin{array}{l}\text { Person } \\
\text { enumerated in } \\
\text { her/his usual } \\
\text { district of } \\
\text { residence }\end{array}$ & $\begin{array}{l}\text { P07 LIVING IN } \\
\text { THIS } \\
\text { TOWN/VILLAGE: } \\
\text { Has (NAME) been } \\
\text { living in this town } \\
\text { or village since } \\
\text { birth? If Yes, go to } \\
\text { P09. }\end{array}$ & $\begin{array}{l}\text { Person who has not } \\
\text { lived in the place of } \\
\text { enumeration for her/his } \\
\text { entire life } \\
\text { A NO answer is a } \\
\text { migrant. }\end{array}$ & $\begin{array}{l}\text { Person who } \\
\text { has lived in } \\
\text { the place of } \\
\text { enumeration } \\
\text { for her/his } \\
\text { entire life } \\
\text { A YES } \\
\text { answer is a } \\
\text { nonmigrant. }\end{array}$ \\
\hline $\begin{array}{l}\text { P08 PLACE OF } \\
\text { RESIDENCE FIVE } \\
\text { YEARS AGO IF } \\
\text { (NAME) IS FIVE } \\
\text { YEARS OR OLDER: } \\
\text { In what district was } \\
\text { (NAME'S) usual } \\
\text { place of residence } \\
\text { five years ago? }\end{array}$ & $\begin{array}{l}\text { Person whose place of } \\
\text { residence at the } 2000 \text { Census } \\
\text { differs from her/his place of } \\
\text { residence in } 1995 \\
\text { Internal migrant }=\text { person who } \\
\text { usually resided in } 1995 \text { in one of } \\
\text { districts outside the district of } \\
\text { enumeration } \\
\text { International migrant = person } \\
\text { who usually resided outside } \\
\text { Ghana in } 1995\end{array}$ & $\begin{array}{l}\text { Person whose } \\
\text { district of } \\
\text { residence at } \\
\text { the } 2000 \\
\text { Census is the } \\
\text { same as that } \\
\text { in } 1995\end{array}$ & $\begin{array}{l}\text { P08 NUMBER OF } \\
\text { YEARS LIVED IN } \\
\text { THIS } \\
\text { TOWN/VILLAGE: } \\
\text { For how long has } \\
\text { (NAME) been living } \\
\text { in this town or } \\
\text { village? }\end{array}$ & $\begin{array}{l}\text { Person who has lived } \\
\text { in the place of } \\
\text { enumeration for a } \\
\text { period less than her/his } \\
\text { age }\end{array}$ & $\begin{array}{l}\text { Person who } \\
\text { has lived in } \\
\text { the place of } \\
\text { enumeration } \\
\text { for her/his } \\
\text { entire life }\end{array}$ \\
\hline
\end{tabular}


Definitions in this paper are consistent with those used by the GSS. "Lifetime migrants" are people whose residence at the census differs from their birthplace (GSS 2013c), with "birthplace" defined as "the town or village (locality) of usual residence of the [infant's] mother at the time of birth" (GSS 1999: 37). "District of usual residence" refers to the district in which the respondent usually resides and may be the place where $\mathrm{s} /$ he was enumerated; however, in cases where respondents maintain multiple residences (e.g., students, military personnel), "usual residence" refers to "where the person spends most of his/her days or time" (GSS 1999: 38). A respondent may also be considered a "usual resident" if s/he has "lived there for at least six months or has the intention of staying for the next six months" (GSS 1999: 38).

\subsection{Methods}

Secondary analyses of the 2000 and 2010 Census microdata were conducted using SPSS Statistics 22.0 and Microsoft Excel 2011 software. We used direct and indirect demographic techniques (UNDESA 1970; Moultrie et al. 2013) to describe the scale, type, and demographic structure (e.g., age, religion, marital status) of contemporary female migration in Ghana and to assess the distribution of female migrants across age and geography. We detail these methods and their assumptions in a technical appendix (Appendix 1).

In order to represent typical age patterns of migration, we fitted a Rogers-Castro multiexponential model migration schedule to observed female migration data (Rogers and Castro 1981; Little and Dorrington 2013) (Appendix 1, Section A-1.1). These schedules, which range from 7 to 13 parameters depending on the model's complexity, depict the dependency between age and migration for use in population projections and in understanding migration dynamics (Little and Dorrington 2013). While not all data will produce a shape compatible with the multiexponential model migration schedule, researchers have successfully fitted the schedule to migration flows in North America, Europe, Asia, and Africa (Little and Dorrington 2013). To examine the effects of demographic indicators on the likelihood of a girl or woman migrating internally in 2000 and 2010, we conducted logistic regression analyses (Appendix 1, Section A-1.2). Binary logistic regression modelled the effects of selected independent variables on whether or not a girl or woman was identified in the census as ever having migrated internally. Selection of the independent variables was based on a literature review of push- and pull-factors of migration. Finally, we generated estimates of net internal female migration between subnational regions from place of birth data (Dorrington 2013) (Appendix 1, Section A-1.3). While we considered estimates produced using the 
cohort component method (Spoorenberg 2015), our estimates of net internal migration from place of birth data appear more robust (Appendix 1, Section A-1.4).

\section{Results}

After first identifying all migrants in the census data, we present analyses of the demographic structure of internal migrants. We then explore the demographic characteristics of female migrants, using regression analyses to explain internal migration status, with "internal migrant" as the dependent variable (yes/no). After examining who migrates, we analyse their migration destinations. The results conclude with analyses of interregional migration, including patterns and trends in the geographic distribution of internal migrants and estimates of interregional female migration between 2000 and 2010 .

\subsection{Identification of migrants}

Migrants in the 2000 and 2010 Censuses were identified and classified according to the criteria in Table 2. The 2000 Census microdata identified a total of 359,960 female internal and international migrants (37.7\% of the female population) and 371,577 male internal and international migrants (39.7\% of the male population) (Appendix 2, Table A-7). In the 2010 microdata, the questions identified 487,376 female internal and international migrants (38.6\% of the female population) and 447,485 male internal and international migrants ( $37.2 \%$ of the male population).

Of the female migrants identified in the 2010 microdata, international migrants comprised $3.1 \%$ of the sample $(15,123)$. The 2000 Census permitted more refined identification of international migrants, since it collected data on place of usual residence at the time of the census and place of usual residence five years prior to the census. In the 2000 microdata, female migrants can be split into 62,929 international migrants (13.5\%) and 402,146 internal migrants (86.5\%). Between 2000 and 2010, the proportion of lifetime internal migrants increased for both females and males $(28.7 \%$ to $35.6 \%$ and $28.1 \%$ to $34.2 \%$ respectively). The relative increase in lifetime migration was greater for females during this period.

At the subnational level, we identified interregional lifetime migration for both sexes using region of birth and region of residence at enumeration (Tables 3 and 4). This identification ignores any interim migration and captures only migration between region of birth and region of residence at enumeration. 
Table 3: Female population classified by region of birth and region of enumeration, Ghana, 2000 and 2010

\begin{tabular}{|c|c|c|c|c|c|c|c|c|c|c|c|}
\hline \multirow{2}{*}{$\begin{array}{l}\text { Region } \\
\text { of birth }\end{array}$} & \multicolumn{11}{|c|}{ Region of enumeration } \\
\hline & Western & Central & $\begin{array}{c}\text { Greater } \\
\text { Accra }\end{array}$ & Volta & Eastern & Ashanti & $\begin{array}{l}\text { Brong } \\
\text { Ahafo }\end{array}$ & Northern & $\begin{array}{c}\text { Upper } \\
\text { East }\end{array}$ & $\begin{array}{l}\text { Upper } \\
\text { West }\end{array}$ & Total \\
\hline \multicolumn{12}{|c|}{ a) Region of birth by region of enumeration at 2000 Census } \\
\hline Western & 642,460 & 16,760 & 28,380 & 2,920 & 8,000 & 21,060 & 5,560 & 1,880 & 1,600 & 1,410 & 730,030 \\
\hline Central & 62,770 & 676,570 & 89,760 & 3,260 & 29,500 & 42,480 & 7,160 & 2,840 & 1,000 & 740 & 916,080 \\
\hline $\begin{array}{l}\text { Greater } \\
\text { Accra }\end{array}$ & 11,700 & 15,640 & 809,900 & 13,850 & 27,230 & 17,310 & 6,220 & 3,420 & 2,230 & 1,420 & 908,920 \\
\hline Volta & 22,260 & 13,250 & 125,930 & 725,740 & 54,130 & 23,840 & 13,520 & 8,610 & 780 & 810 & 988,870 \\
\hline Eastern & 29,300 & 21,540 & 162,960 & 11,400 & 858,730 & 37,760 & 8,970 & 2,120 & 1,420 & 930 & $1,135,130$ \\
\hline Ashanti & 44,500 & 15,970 & 78,680 & 5,070 & 19,850 & $1,304,400$ & 36,120 & 7,360 & 8,830 & 5,340 & $1,526,120$ \\
\hline $\begin{array}{l}\text { Brong } \\
\text { Ahafo }\end{array}$ & 28,420 & 3,300 & 16,980 & 2,130 & 5,150 & 35,620 & 683,910 & 5,640 & 2,310 & 3,390 & 786,850 \\
\hline Northern & 8,870 & 3,020 & 23,010 & 14,910 & 5,600 & 31,620 & 27,290 & 821,860 & 4,020 & 2,660 & 942,860 \\
\hline $\begin{array}{l}\text { Upper } \\
\text { East }\end{array}$ & 19,410 & 2,550 & 12,680 & 960 & 4,480 & 42,890 & 23,720 & 10,410 & 422,900 & 1,440 & 541,440 \\
\hline $\begin{array}{l}\text { Upper } \\
\text { West }\end{array}$ & 12,370 & 1,890 & 9,710 & 810 & 3,860 & 22,890 & 40,210 & 12,700 & 2,200 & 264,120 & 370,760 \\
\hline Total & 882,060 & 770,490 & $1,357,990$ & 781,050 & $1,016,530$ & $1,579,870$ & 852,680 & 876,840 & 447,290 & 282,260 & $8,847,060$ \\
\hline \multicolumn{12}{|c|}{ b) Region of birth by region of enumeration at 2010 Census } \\
\hline Western & 909,160 & 30,970 & 43,610 & 3,640 & 11,730 & 40,980 & 10,090 & 1,210 & 1,600 & 1,540 & $1,054,530$ \\
\hline Central & 71,810 & 945,810 & 136,770 & 4,840 & 35,330 & 58,510 & 8,150 & 1,880 & 590 & 650 & $1,264,340$ \\
\hline $\begin{array}{l}\text { Greater } \\
\text { Accra }\end{array}$ & 15,150 & 43,100 & $1,188,210$ & 19,930 & 37,770 & 25,650 & 7,480 & 3,620 & 2,510 & 1,480 & $1,344,900$ \\
\hline Volta & 23,340 & 22,980 & 180,300 & $1,000,130$ & 63,580 & 26,720 & 15,900 & 8,660 & 880 & 710 & $1,343,200$ \\
\hline Eastern & 28,610 & 38,450 & 245,430 & 15,380 & $1,123,500$ & 46,750 & 10,290 & 1,830 & 1,030 & 1,000 & $1,512,270$ \\
\hline Ashanti & 41,350 & 29,580 & 125,150 & 7,230 & 28,910 & $2,011,670$ & 44,260 & 7,620 & 12,740 & 5,230 & $2,313,740$ \\
\hline $\begin{array}{l}\text { Brong } \\
\text { Ahafo }\end{array}$ & 27,870 & 7,730 & 32,930 & 3,850 & 8,780 & 77,220 & 943,410 & 6,700 & 2,550 & 5,170 & $1,116,210$ \\
\hline Northern & 18,190 & 6,950 & 49,480 & 17,280 & 10,890 & 61,570 & 40,740 & $1,190,720$ & 5,970 & 3,620 & $1,405,410$ \\
\hline $\begin{array}{l}\text { Upper } \\
\text { East }\end{array}$ & 21,250 & 3,850 & 20,530 & 910 & 6,610 & 66,430 & 29,680 & 9,560 & 500,400 & 2,230 & 661,450 \\
\hline $\begin{array}{l}\text { Upper } \\
\text { West } \\
\end{array}$ & 13,370 & 2,050 & 9,910 & 610 & 4,170 & 28,600 & 50,520 & 11,820 & 2,770 & 334,880 & 458,700 \\
\hline Total & $1,170,100$ & $1,131,470$ & $2,032,320$ & $1,073,800$ & $1,331,270$ & $2,444,100$ & $1,160,520$ & $1,243,620$ & 531,040 & 356,510 & $12,474,750$ \\
\hline
\end{tabular}


Lattof et al.: Contemporary female migration in Ghana: Analyses of the 2000 and 2010 Censuses

Table 4: Male population classified by region of birth and region of enumeration, Ghana, 2000 and 2010

\begin{tabular}{|c|c|c|c|c|c|c|c|c|c|c|c|}
\hline \multirow{2}{*}{$\begin{array}{l}\text { Region } \\
\text { of birth }\end{array}$} & \multicolumn{11}{|c|}{ Region of enumeration } \\
\hline & Western & Central & $\begin{array}{c}\text { Greater } \\
\text { Accra }\end{array}$ & Volta & Eastern & Ashanti & $\begin{array}{l}\text { Brong } \\
\text { Ahafo }\end{array}$ & Northern & $\begin{array}{l}\text { Upper } \\
\text { East }\end{array}$ & $\begin{array}{l}\text { Upper } \\
\text { West }\end{array}$ & Total \\
\hline \multicolumn{12}{|c|}{ a) Region of birth by region of enumeration at 2000 Census } \\
\hline Western & 613,470 & 14,430 & 26,760 & 2,620 & 7,390 & 19,710 & 5,580 & 1,750 & 1,870 & 1,440 & 695,020 \\
\hline Central & 62,760 & 593,640 & 85,470 & 3,460 & 25,960 & 43,890 & 8,380 & 3,470 & 910 & 520 & 828,460 \\
\hline $\begin{array}{l}\text { Greater } \\
\text { Accra }\end{array}$ & 13,890 & 15,600 & 769,250 & 14,930 & 27,750 & 19,980 & 7,480 & 3,620 & 2,480 & 1,200 & 876,180 \\
\hline Volta & 25,450 & 13,360 & 122,100 & 665,010 & 52,970 & 26,210 & 14,590 & 9,030 & 1,090 & 780 & 930,590 \\
\hline Eastern & 33,250 & 21,020 & 151,680 & 10,780 & 804,890 & 39,620 & 9,700 & 2,330 & 1,540 & 790 & $1,075,600$ \\
\hline Ashanti & 48,040 & 15,600 & 80,840 & 4,170 & 18,940 & $1,222,970$ & 34,200 & 7,190 & 8,850 & 4,610 & $1,445,410$ \\
\hline $\begin{array}{l}\text { Brong } \\
\text { Ahafo }\end{array}$ & 30,760 & 3,690 & 17,350 & 2,210 & 5,170 & 35,070 & 647,860 & 5,340 & 2,530 & 2,600 & 752,580 \\
\hline Northern & 10,710 & 3,630 & 23,200 & 14,170 & 7,260 & 35,630 & 32,400 & 796,510 & 3,680 & 2,510 & 929,700 \\
\hline $\begin{array}{l}\text { Upper } \\
\text { East }\end{array}$ & 23,880 & 2,890 & 14,600 & 1,070 & 6,230 & 49,060 & 29,090 & 8,390 & 372,130 & 1,040 & 508,380 \\
\hline $\begin{array}{l}\text { Upper } \\
\text { West }\end{array}$ & 13,780 & 1,940 & 8,700 & 1,060 & 5,310 & 27,470 & 49,760 & 12,530 & 2,090 & 242,230 & 364,870 \\
\hline Total & 875,990 & 685,800 & $1,299,950$ & 719,480 & 961,870 & $1,519,610$ & 839,040 & 850,160 & 397,170 & 257,720 & $8,406,790$ \\
\hline \multicolumn{12}{|c|}{ b) Region of birth by region of enumeration at 2010 Census } \\
\hline Western & 874,870 & 25,780 & 38,060 & 2,790 & 10,360 & 37,300 & 11,550 & 1,070 & 1,730 & 1,640 & $1,005,150$ \\
\hline Central & 72,240 & 850,070 & 117,280 & 4,790 & 31,750 & 54,310 & 9,030 & 1,880 & 800 & 810 & $1,142,960$ \\
\hline $\begin{array}{l}\text { Greater } \\
\text { Accra }\end{array}$ & 20,080 & 41,520 & $1,137,810$ & 20,680 & 36,550 & 27,510 & 9,220 & 3,800 & 3,370 & 1,700 & $1,302,240$ \\
\hline Volta & 27,770 & 25,350 & 164,370 & 922,570 & 63,920 & 31,140 & 18,380 & 8,050 & 1,240 & 700 & $1,263,490$ \\
\hline Eastern & 34,700 & 37,390 & 211,150 & 14,320 & $1,071,690$ & 46,210 & 11,210 & 2,130 & 1,600 & 910 & $1,431,310$ \\
\hline Ashanti & 50,080 & 31,680 & 123,980 & 6,700 & 27,270 & $1,868,170$ & 47,390 & 7,400 & 12,710 & 5,840 & $2,181,220$ \\
\hline $\begin{array}{l}\text { Brong } \\
\text { Ahafo }\end{array}$ & 32,480 & 9,420 & 29,570 & 3,330 & 9,300 & 66,940 & 895,440 & 6,250 & 2,480 & 4,430 & $1,059,640$ \\
\hline Northern & 21,890 & 7,840 & 45,020 & 16,990 & 13,680 & 61,050 & 47,070 & $1,172,660$ & 5,250 & 4,200 & $1,395,650$ \\
\hline $\begin{array}{l}\text { Upper } \\
\text { East }\end{array}$ & 26,540 & 5,250 & 20,180 & 910 & 7,460 & 65,630 & 33,050 & 7,150 & 471,290 & 1,610 & 639,070 \\
\hline $\begin{array}{l}\text { Upper } \\
\text { West }\end{array}$ & 14,880 & 2,650 & 7,240 & 680 & 6,190 & 27,940 & 55,620 & 10,430 & 1,820 & 315,410 & 442,860 \\
\hline Total & $1,175,530$ & 6,950 & $1,894,660$ & 993,760 & 8,170 & 86,200 & 137,960 & $1,220,820$ & 502,290 & 337,25 & 363,590 \\
\hline
\end{tabular}

Figures 2 and 3 condense these migration streams by sex into noncumulative, stacked column charts that compare the totals (i.e., net lifetime migration) and their shares (i.e., lifetime out-migrants, lifetime in-migrants) (Appendix 2, Tables A-8 and A-9). Four regions experienced population gains in net lifetime migration streams by 
both sexes in 2000 and 2010: Greater Accra, Western, Ashanti, and Brong Ahafo. The remaining six regions experienced net losses by both sexes in 2000 and 2010.

Figure 2: Lifetime female migration streams, Ghana, 2000 (blue) and 2010 (red)

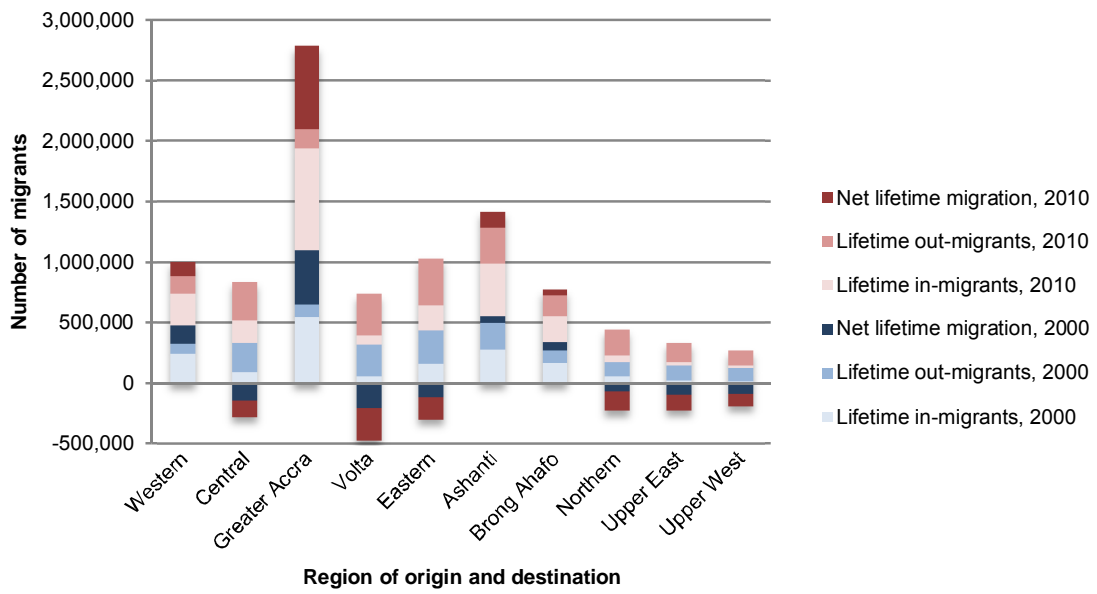

Figure 3: Lifetime male migration streams, Ghana, 2000 (blue) and 2010 (red)

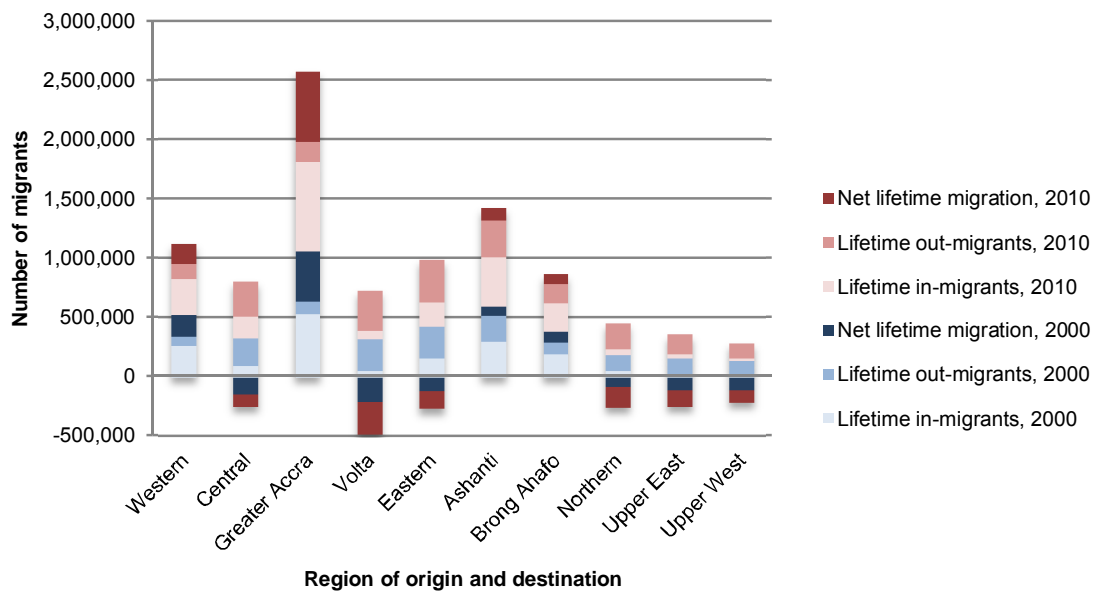




\subsection{Demographic structure of internal migrants}

Disaggregating internal migrants by age and sex highlights changes between groups and over time. Though Ghanaians migrate at all ages, the mean age of internal migrants increased over time. From 2000 to 2010, the mean age of female internal migrants rose from 27.39 years (s.d. 18.86) to 29.71 years (s.d. 18.69). Males showed a similar trend, with the mean age of internal migrants increasing from 28.48 years (s.d. 19.57) to 29.71 years (s.d. 18.62) between 2000 and 2010.

Examining the distribution of migrants and nonmigrants by five-year age groups indicates growing relative migration between 2000 and 2010. In 2000, female nonmigrants outweighed female migrants in each five-year age group (Figure 4, top). By 2010, the percentage of female migrants overtook female nonmigrants among women aged between 25 and 49 years (Figure 4, bottom). For males in 2000, nonmigrants comprised a greater percentage of each age group than migrants, with the exception of the age group 45-49 years (Figure 5, top). By 2010, male migrants outweighed male nonmigrants among men aged between 30 and 59 years (Figure 5, bottom). Working-age migration was particularly pronounced in 2010 for both men and women.

The age-related distribution of female and male regional out-migrants was assessed in greater detail using multiexponential model migration schedules (Figure 6) for age cohorts $x-5$ to $\mathrm{x}$ over the period 1995-2000. Since retirement was not concentrated among specific ages in this data and the data may exaggerate older ages (Little and Dorrington 2013), the standard 7-parameter model fitted the observed data better than the more complex 9-, 11-, or 13-parameter models, which account for more complex components such as retirement peaks and post-retirement up-slopes. The mean absolute percentage error statistic, $7 \%$ for both sexes, is within the boundaries for achieving a reasonable fit. The R-squared values for males (92\%) and females (89\%) are acceptable compared to the established threshold of $90 \%$, indicating that the models reasonably fit the data (Little and Dorrington 2013). T-statistics are significant at the 0.05 level for all coefficients. For both sexes, the rate of ascent of the labour force component is greater than the rate of this component's descent. Female migration propensity rises sharply from the age of 10 , peaking at 0.09097 at the age of 23 years. Male migration propensity peaks several years later at 0.10204 at the age of 27 years. 
Figure 4: Female population pyramid by migrant status, 2000 Census (top) and 2010 Census (bottom)

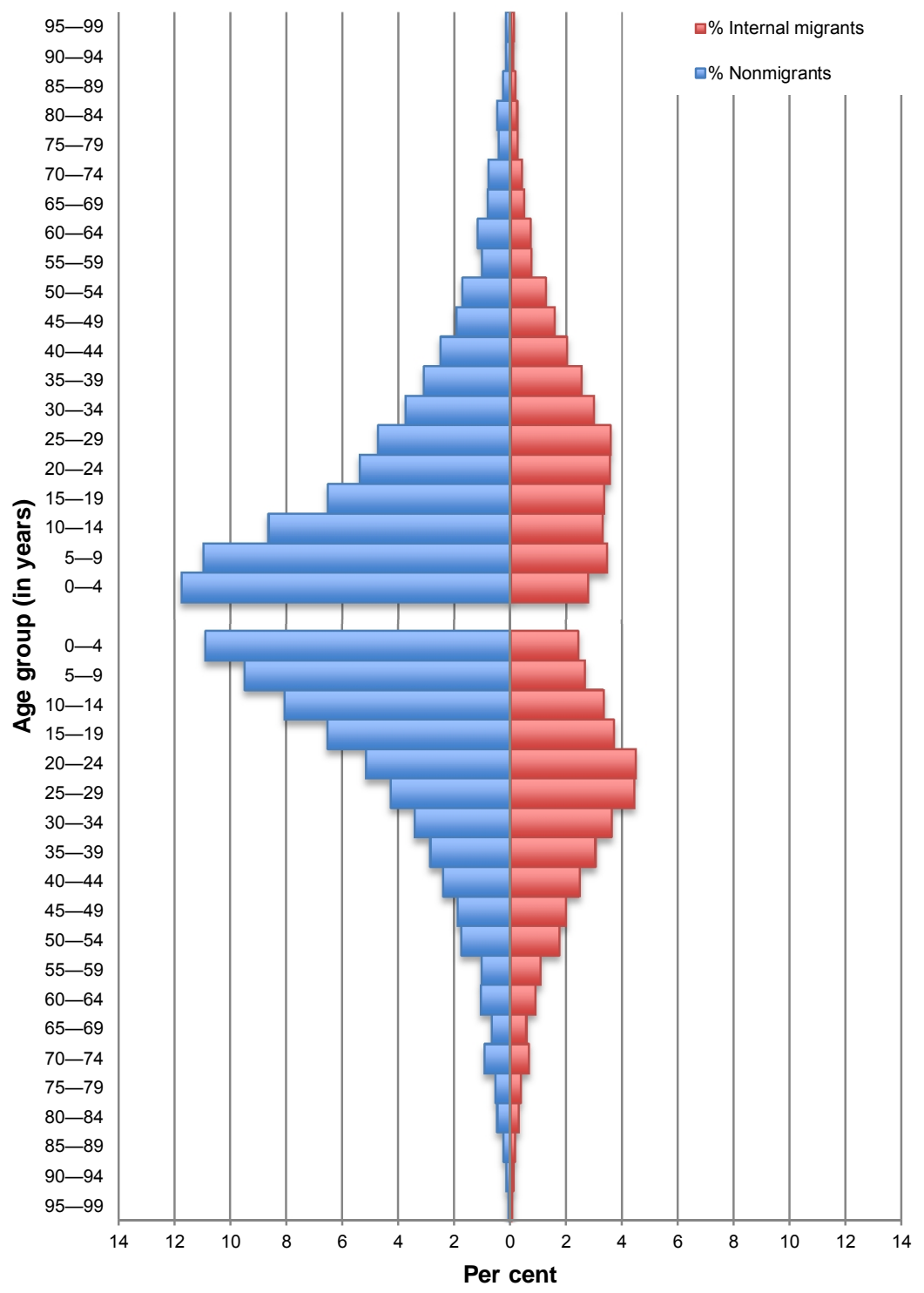


Figure 5: Male population pyramid by migrant status, 2000 Census (top) and 2010 Census (bottom)

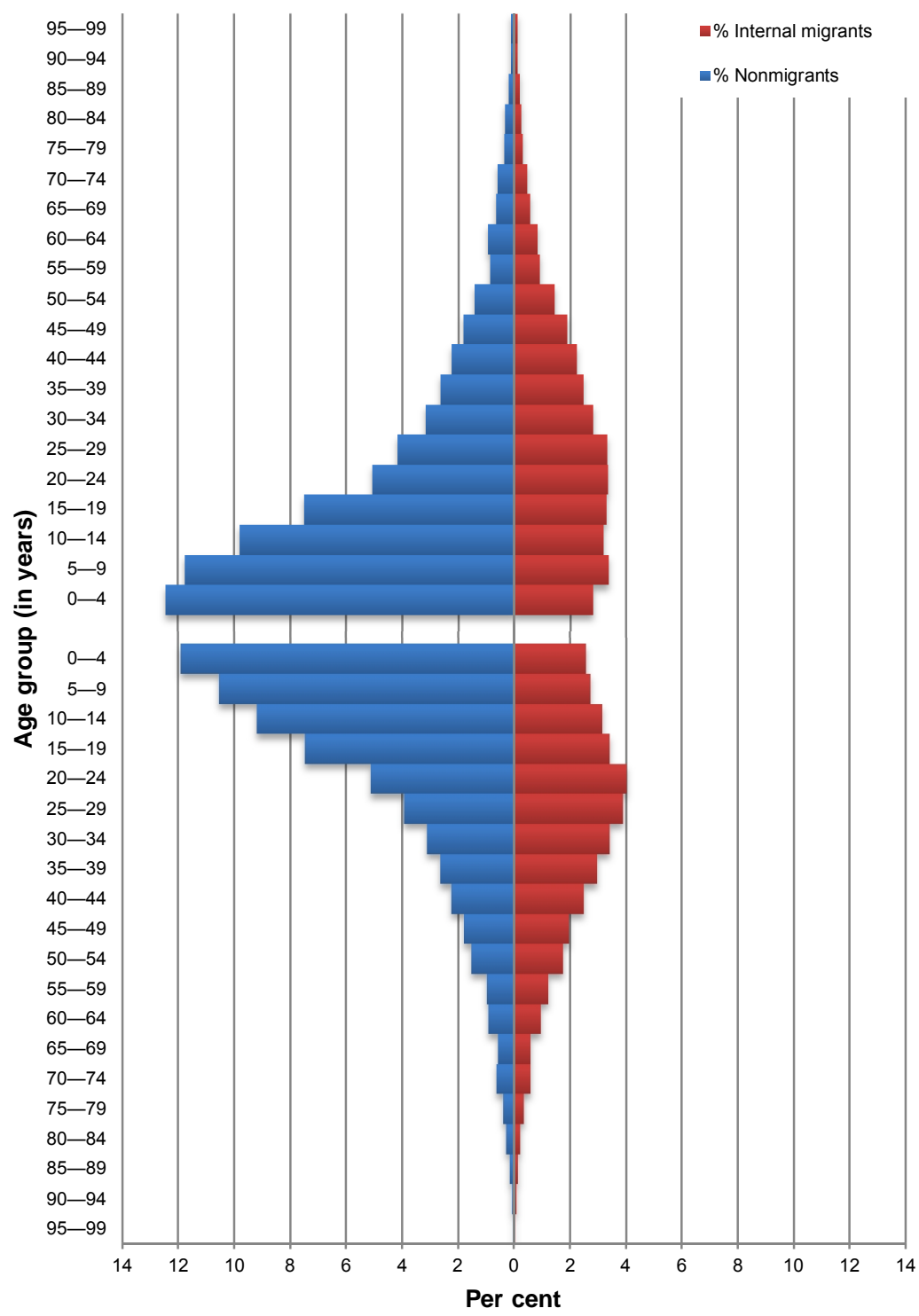


Figure 6: Regional out-migration by sex over the five-year interval, 1995-2000, and fitted with a 7-parameter model schedule, Ghana, 2000 Census $10 \%$ microdata

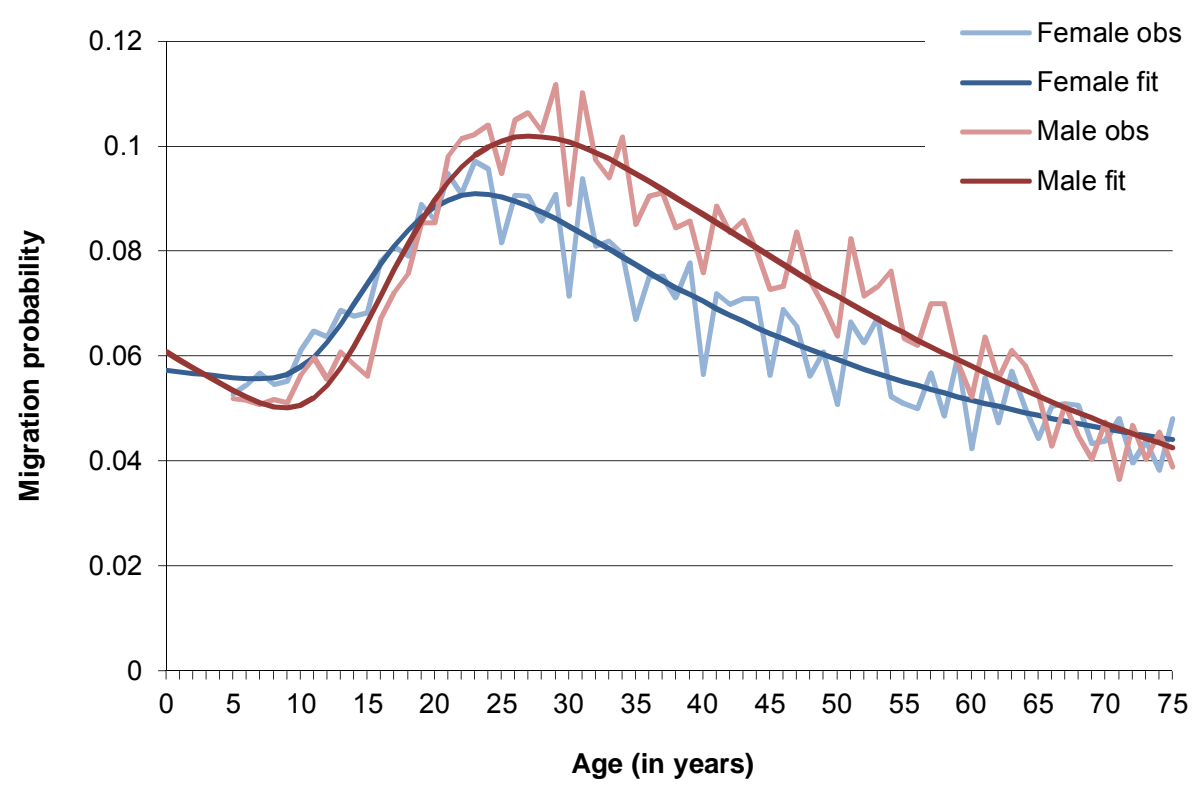

After identifying all female internal migrants in the microdata and examining migrant status by sex and age, we analysed the effects of demographic indicators on the likelihood of a girl or woman being identified as an internal migrant (Table 5). International migrants are excluded from these regression analyses. Age, in five-year age groups, and education status were nonsignificant predictors. These variables are excluded from the final models for 2000 and 2010, as they worsened or did not significantly improve the models' ability to predict internal migrant status. The model for 2000 accurately predicts $63.5 \%$ of cases, predicting nonmigrants $(85.1 \%)$ better than internal migrants (29.7\%). The 2010 model improves the accuracy of predicting internal migrants $(51.1 \%)$. It accurately predicts $65.7 \%$ of cases, including $75.5 \%$ of nonmigrants. Difficulties in accurately determining migrant status based on census data are likely to affect the models' predictive abilities. Although both models have low Rsquared values, they also have statistically significant predictors that can be used to draw conclusions about migrant status. 
Lattof et al.: Contemporary female migration in Ghana: Analyses of the 2000 and 2010 Censuses

Table 5: Regression results explaining female internal migration status in Ghana, 2000 and 2010 Census microdata, with internal migrant as the dependent variable

\begin{tabular}{|c|c|c|c|c|c|c|c|}
\hline \multirow{2}{*}{\multicolumn{2}{|c|}{$\begin{array}{l}\text { Demographic characteristics } \\
\text { (Independent variables) }\end{array}$}} & \multicolumn{3}{|l|}{2000} & \multicolumn{3}{|l|}{2010} \\
\hline & & \multirow{2}{*}{$\begin{array}{l}\begin{array}{l}\text { Odds } \\
\text { ratio }\end{array} \\
\text { Ref }\end{array}$} & \multirow{2}{*}{$\begin{array}{l}\text { Std. Error } \\
-\end{array}$} & \multirow{2}{*}{$\begin{array}{l}95 \% \text { C.I. } \\
-\end{array}$} & \multirow{2}{*}{$\begin{array}{l}\begin{array}{l}\text { Odds } \\
\text { ratio }\end{array} \\
\text { Ref }\end{array}$} & \multirow{2}{*}{$\begin{array}{l}\text { Std. Error } \\
-\end{array}$} & \multirow{2}{*}{$\frac{95 \% \text { C.I. }}{-}$} \\
\hline & Rural & & & & & & \\
\hline Residence & Urban & 1.377 & 0.006 & $1.362-1.393$ & 1.602 & 0.004 & $1.589-1.616$ \\
\hline \multirow{6}{*}{ Marital status } & Never married & Ref & - & - & Ref & - & - \\
\hline & Married & 0.999 & 0.009 & $0.982-1.017$ & 0.981 & 0.007 & $0.967-0.994$ \\
\hline & Consensual union† & 0.937 & 0.013 & $0.914-0.960$ & 1.000 & 0.011 & $0.979-1.022$ \\
\hline & Separated & 0.902 & 0.021 & $0.866-0.940$ & 0.834 & 0.016 & $0.809-0.860$ \\
\hline & Divorced & 0.758 & 0.014 & $0.737-0.780$ & 0.827 & 0.012 & $0.808-0.847$ \\
\hline & Widowed & 0.775 & 0.014 & $0.755-0.796$ & 0.804 & 0.010 & $0.788-0.821$ \\
\hline \multirow{2}{*}{$\begin{array}{l}\text { Worked for pay, } \\
\text { profit, or family gain }\end{array}$} & Did not work & Ref & - & - & Ref & - & - \\
\hline & Worked & 1.117 & 0.006 & $1.104-1.130$ & 1.097 & 0.005 & $1.086-1.107$ \\
\hline \multirow{13}{*}{$\begin{array}{l}\text { Relationship to } \\
\text { head of household }\end{array}$} & Head & Ref & - & - & Ref & - & - \\
\hline & Nonrelative & 1.952 & 0.018 & $1.886-2.021$ & 2.091 & 0.009 & $2.024-2.161$ \\
\hline & Temporary head $\ddagger$ & 1.355 & 0.018 & $1.309-1.403$ & - & - & - \\
\hline & Group quarters§ & 4.468 & 0.074 & $3.861-5.169$ & 1.320 & 0.015 & $1.283-1.358$ \\
\hline & Spouse & 1.401 & 0.010 & $1.375-1.428$ & 1.271 & 0.007 & $1.252-1.289$ \\
\hline & Child & 0.519 & 0.011 & $0.508-0.529$ & 0.356 & 0.008 & $0.350-0.361$ \\
\hline & Parent or parent-in-law & 1.190 & 0.021 & $1.142-1.241$ & 1.017 & 0.016 & $0.986-1.049$ \\
\hline & Daughter-in-law & 1.055 & 0.022 & $1.010-1.102$ & 0.758 & 0.020 & $0.729-0.789$ \\
\hline & Grandchild & 0.397 & 0.019 & $0.382-0.412$ & 0.294 & 0.012 & $0.287-0.300$ \\
\hline & Sisterf & - & - & - & 0.787 & 0.011 & $0.769-0.804$ \\
\hline & Stepchild $\ddagger$ & - & - & - & 0.547 & 0.025 & $0.521-0.574$ \\
\hline & Adopted/ foster child $\ddagger$ & - & - & - & 0.724 & 0.031 & $0.681-0.769$ \\
\hline & Other relative & 1.156 & 0.010 & $1.134-1.178$ & 0.914 & 0.009 & $0.898-0.930$ \\
\hline \multirow{9}{*}{ Religion } & No religion & Ref & - & - & Ref & - & - \\
\hline & Catholic & 0.918 & 0.014 & $0.893-0.944$ & 1.178 & 0.012 & $1.150-1.206$ \\
\hline & Protestant & 1.019 & 0.014 & $0.991-1.046$ & 1.277 & 0.012 & $1.248-1.307$ \\
\hline & Pentecostalף & 1.154 & 0.014 & $1.124-1.185$ & 1.561 & 0.011 & $1.527-1.597$ \\
\hline & Other Christian & 1.033 & 0.015 & $1.003-1.063$ & 1.294 & 0.012 & $1.263-1.326$ \\
\hline & Muslim & 0.616 & 0.015 & $0.598-0.634$ & 0.758 & 0.012 & $0.740-0.776$ \\
\hline & Ahmadif & - & - & - & 1.118 & 0.029 & $1.057-1.182$ \\
\hline & Traditional & 0.397 & 0.017 & $0.384-0.410$ & 0.516 & 0.015 & $0.501-0.532$ \\
\hline & Other & 1.158 & 0.034 & $1.082-1.239$ & 1.285 & 0.025 & $1.223-1.350$ \\
\hline \multicolumn{2}{|l|}{$\overline{\text { Cox \& Snell R }}{ }^{2}$} & 0.067 & & & 0.105 & & \\
\hline \multicolumn{2}{|l|}{ Nagelkerke $\mathrm{R}^{2}$} & 0.090 & & & 0.142 & & \\
\hline
\end{tabular}

Notes: † In 2010 this category included informal unions and living together. $\ddagger$ This response category is included in only one census. § Group quarters included members of nonhousehold populations (e.g., nurses working the night shift) and referred to places such as hotels, orphanages, universities, prisons, and hospitals. If In 2010 the category Pentecostal included respondents who identified as Charismatic.

Being a female migrant is significantly associated with residing in an urban area, indicating the prominence of rural-urban migration. Residing at a residence where relationship to the household head is group quarters, nonrelative, temporary head, 
spouse, or parent/parent-in-law also increases a census respondent's odds of being identified as an internal migrant. Female migrants are more likely than nonmigrants to report working for pay, profit, or family gain, suggesting that economic opportunity is a likely driver of migration. By 2010, female migrants are likelier to have never married than be married. Female census respondents are substantially less likely to be identified as internal migrants in 2000 and 2010 if they practise a traditional religion or Islam and if they are the children of the household head.

\subsection{Interregional female migration}

Key features of Ghanaian female internal migration include the high concentration of intraregional migration within all regions and out-migration from the Upper East, Upper West, Northern, Volta, and Central Regions, with no significant in-migration. The Greater Accra Region exhibited significant in-migration from all but three regions (Upper West, Upper East, and Brong Ahafo).

The importance of the Greater Accra and Ashanti Regions as internal migration destinations is further underscored by examination of interregional female migration streams between 1995 and 2000. Using five-year fixed-interval data from the 2000 Census, we calculated interregional female migration streams between 1995 and 2000 in Ghana in the population aged five years and older. Table 6 depicts destinationspecific out-migration rates for each of Ghana's regions, producing a five-year migration rate for females who survived the period 1995-2000. Three of the five highest migration rates are among females migrating to Greater Accra from the Volta (0.0180), Eastern (0.0172), and Central Regions (0.0138). The highest rate is among females in the Western Region migrating to the Central Region (0.0218). The highest rates of migrants to the Ashanti Region are among females migrating from the Upper East (0.0129) and Brong Ahafo (0.0119) Regions.

Regional estimates of the net number of interregional female in-migrants from 2000 to 2010 (Appendix 2, Table A-10) show that Greater Accra received the largest number of female migrants among all age groups. Of Ghana's estimated 804,365 total female in-migrants (Table 7), nearly half (43.56\%) migrated into Greater Accra, with the Ashanti Region, home to Ghana's second largest city, receiving $22.47 \%$ of female in-migrants. The lowest levels of in-migrants are in northern Ghana, with a net number of 662 girls and women migrating into the Northern Region $(0.08 \%)$ and 6,823 migrating into the Upper East Region (0.85\%). Negative numbers in Table A-10 indicate negative net in-migration. The Upper West is the only region to experience overall net negative in-migration. Net in-migration in the Upper West Region for 2000 and 2010 is positive only among girls aged $0-4$ years. 
Lattof et al.: Contemporary female migration in Ghana: Analyses of the 2000 and 2010 Censuses

Table 6: Female interregional migration rates in 2000 as proportions of survivors of the 1995 population, female population aged five years and older

\begin{tabular}{|c|c|c|c|c|c|c|c|c|c|c|c|}
\hline \multirow{2}{*}{$\begin{array}{l}\text { Region of } \\
\text { residence, } \\
1995\end{array}$} & \multicolumn{11}{|c|}{ Region of residence at census, 2000} \\
\hline & Western & Central & $\begin{array}{c}\text { Greater } \\
\text { Accra }\end{array}$ & Volta & Eastern & Ashanti & $\begin{array}{l}\text { Brong } \\
\text { Ahafo }\end{array}$ & Northern & $\begin{array}{c}\text { Upper } \\
\text { East }\end{array}$ & $\begin{array}{l}\text { Upper } \\
\text { West }\end{array}$ & Total \\
\hline Western & - & 0.0218 & 0.0067 & 0.0025 & 0.0041 & 0.0099 & 0.0037 & 0.0007 & 0.0019 & 0.0023 & 0.0537 \\
\hline Central & 0.0098 & - & 0.0138 & 0.0016 & 0.0052 & 0.0065 & 0.0012 & 0.0005 & 0.0005 & 0.0002 & 0.0394 \\
\hline $\begin{array}{l}\text { Greater } \\
\text { Accra }\end{array}$ & 0.0038 & 0.0080 & - & 0.0170 & 0.0086 & 0.0043 & 0.0014 & 0.0009 & 0.0011 & 0.0040 & 0.0490 \\
\hline Volta & 0.0032 & 0.0028 & 0.0180 & - & 0.0081 & 0.0029 & 0.0015 & 0.0014 & 0.0006 & 0.0005 & 0.0390 \\
\hline Eastern & 0.0032 & 0.0043 & 0.0172 & 0.0046 & - & 0.0066 & 0.0016 & 0.0005 & 0.0006 & 0.0008 & 0.0394 \\
\hline Ashanti & 0.0058 & 0.0033 & 0.0072 & 0.0016 & 0.0036 & - & 0.0085 & 0.0012 & 0.0017 & 0.0062 & 0.0391 \\
\hline Brong Ahafo & 0.0053 & 0.0015 & 0.0042 & 0.0016 & 0.0022 & 0.0119 & - & 0.0037 & 0.0023 & 0.0037 & 0.0365 \\
\hline Northern & 0.0018 & 0.0007 & 0.0046 & 0.0028 & 0.0017 & 0.0058 & 0.0044 & - & 0.0018 & 0.0015 & 0.0251 \\
\hline Upper East & 0.0079 & 0.0020 & 0.0043 & 0.0011 & 0.0021 & 0.0129 & 0.0055 & 0.0041 & - & 0.0008 & 0.0408 \\
\hline Upper West & 0.0077 & 0.0008 & 0.0043 & 0.0008 & 0.0016 & 0.0092 & 0.0128 & 0.0058 & 0.0010 & - & 0.0441 \\
\hline
\end{tabular}

Note: Interregional migration rates over 0.0100 are emphasized in bold.

Table 7: $\quad$ Estimates of overall net female out-migrants, in-migrants, and migration streams, Ghana, 2000 to 2010

\begin{tabular}{lccccc}
\hline $\begin{array}{l}\text { Region of origin and } \\
\text { destination }\end{array}$ & $\begin{array}{l}\text { Net in-migrants } \\
\text { Total }\end{array}$ & \multicolumn{1}{c}{$\%$} & Net out-migrants & Total & $\begin{array}{l}\text { Overall net } \\
\text { migration }\end{array}$ \\
\hline Western & 42,208 & 5.25 & 55,919 & 6.83 & $-13,711$ \\
Central & 91,774 & 11.41 & 107,894 & 13.19 & $-16,121$ \\
Greater Accra & 350,391 & 43.56 & 50,179 & 6.13 & 300,213 \\
Volta & 8,186 & 1.02 & 109,747 & 13.41 & $-101,561$ \\
Eastern & 70,757 & 8.80 & 141,887 & 17.34 & $-71,130$ \\
Ashanti & 180,774 & 22.47 & 79,344 & 9.70 & 101,431 \\
Brong Ahafo & 64,635 & 8.04 & 79,573 & 9.73 & $-14,939$ \\
Northern & 662 & 0.08 & 109,747 & 13.41 & $-109,085$ \\
Upper East & 6,823 & 0.85 & 54,035 & 6.60 & $-47,212$ \\
Upper West & $-11,844$ & -1.47 & 29,890 & 3.65 & $-41,734$ \\
\hline Total & 804,365 & 100 & 818,215 & 100 & $-13,849$ \\
\hline
\end{tabular}

Regional estimates of the net number of female out-migrants (Appendix 2, Table A-11) show that the net out-migration was highest in the Eastern Region. Of Ghana's 818,215 total female out-migrants (Table 7), 17.34\% migrated from the Eastern Region, followed by the Northern and Volta Regions (13.41\% each). Net out-migration was 
smallest in the Upper West Region with 29,890 female out-migrants (3.65\%), followed by Greater Accra with 50,179 female out-migrants (6.13\%).

Negative numbers in Table A-11, such as among girls aged 5-14 years in the Upper West Region, indicate negative net out-migration. Among young girls in the Volta, Upper East, and Upper West Regions, the negative out-migration suggests that these children are likely to be returning home with a mother or father who was working outside the region. Among women aged 55 years and older in the Greater Accra, Western, Northern, Upper East, and Upper West Regions, negative out-migration suggests return migration of retiring workers.

Combining estimates of net in-migration and net out-migration reveals that net out-migration exceeds net in-migration in eight of Ghana's ten regions. Only the Greater Accra and Ashanti Regions have positive net overall migration (Table 7). By contrast, overall net migration is lowest in the Northern and Volta Regions, with more girls and women moving out of the regions than moving into them.

\section{Discussion}

Our analyses reveal that the overwhelming focus of previous research on male internal migrants is misplaced. Internal migration in Ghana involves both sexes and warrants greater attention to sex-disaggregated analyses. Our analyses reveal that recent migration in Ghana is sex-balanced, according to the $47 \%-53 \%$ typology put forward by Donato and Gabaccia (2015). Ghanaian girls and women migrate at all ages, and approximately $40 \%-50 \%$ of these migrants are within age groups excluded from noncensus sources of national migration data (e.g., GDHS). Working-age migration is a key feature of migration for both sexes, peaking at earlier ages for females than males. Being a female migrant is significantly associated with residing in an urban area and working for pay, profit, or family gain. These findings suggest that economic opportunity is an important driver of female migration.

Advancing our understanding of gender and migration requires paying greater attention to examining differences between the migration patterns of women and men. The historical narrative of the "passive" female migrant has no place in today's evidence. The regression results indicate increased mobility and independence among female migrants, as reflected in their living situations. Female migrants exhibit greater odds of residing in group quarters, in a household where they are the temporary head of household, or in a household with a nonrelative head of the household. Moving with a spouse is no longer a precursor to female migration. By 2010, married women were less likely to migrate than peers who had never married. 
Only the Greater Accra and Ashanti Regions, home to Ghana's two largest cities, have positive net overall migration. With net out-migration exceeding net in-migration in eight of Ghana's ten regions, productive female labour losses may have a negative impact on local development efforts and local economies. The prominence of the Greater Accra and Ashanti Regions as destinations for female migrants suggests that interventions are needed in Ghana's more rural regions to reduce poverty and develop greater economic opportunities for girls and women.

Ghana's kayayei have become a visible sign of changing internal migration patterns. This growing population represents the face of female north-south, ruralurban migration in Ghana, with most migrant female youth becoming porters on arrival in Accra (Kwankye and Addoquaye Tagoe 2009). Though kayayei exist in Ghana's second and third largest cities, Kumasi and Tamale, their presence in the capital has generated particular policy concerns (Parliament 2016). There is no accurate and reliable data on the number of kayayei; estimates range from 2,300 to 160,000 in Accra (Kearney 2013; Parliament 2016). Such variation in the estimates reveals a need for improved data on and reporting of female internal migration if policymakers are to address development-related issues in the sending and receiving communities.

Our analyses highlight the valuable information that census data provides on migration's demographic structure, patterns, and trends. Recent collaborations between the GSS and the International Organization for Migration suggest that future data collection activities in Ghana will pay greater attention to migration; however, existing census data presents an incomplete picture of contemporary female migration. Resource constraints in census offices, the expense of implementing a census, the balance of interests among census committee members, and political priorities frequently limit the number of migration questions in census questionnaires. Censuses also fail to capture migrants' underlying motivations and migration experiences.

Census analyses reveal a need for researchers to bring a gendered lens to issues such as drivers of migration, impacts of migration, and links between migration and health. Census data reveals nothing about migrants' and nonmigrants' opportunities or their perceptions of the costs and gains of migration. Breastfeeding infants may migrate with their mothers out of necessity, and girls from large families may be fostered out to aunts or other relatives. Preadolescent girls may independently decide to migrate in search of ways to pay their school fees. Censuses also miss the social and economic contributions that migrants make to their families and communities. Too often the lack of data on female migrants' contributions reinforces the outdated stereotype that girls and women take passive roles in migration. Ad hoc subnational surveys and more detailed interviews can address these aspects of migration in greater depth, complementing national-level census analyses and presenting a completer picture of contemporary migration. 
The 2000 and 2010 Censuses have several limitations. Since the post-enumeration survey data collected after the 2000 Census is unavailable, it is impossible to assess the quality of the 2000 Census and whether the results required adjustment. Furthermore, the microdata from the 2000 Census is less representative of the national population than the microdata from the 2010 Census. While the post-enumeration survey conducted after the 2010 Census revealed no need to adjust the final results, the 2010 Census reportedly struggled to enumerate highly mobile populations like the kayayei (Daily Express 2010). It is possible that such migrant groups may be underrepresented, particularly if enumerators attempted to enumerate them during working hours or were unprepared to capture mobile populations' large numbers. Additional data limitations include possible reference period error for the question asking about place of residence five years prior, potential uncertainty about exact geographic boundaries, and problems reporting age.

One particular conceptual challenge is that the census questionnaires' understanding and measuring of migration do not capture contemporary migration patterns identified via other sources of migration data. Most movements between place of birth and current residence are missing. The censuses fail to capture cyclical and short-term migrations, which are commonplace in Ghana, as well as seasonal or repeat migrations and migration histories. The censuses also struggle to capture migration duration and meaningful data on intraregional migration, which is more common than interregional migration. These challenges have implications for the types of migrants and migrations that are identified and included in national analyses. Identifying these types of migration patterns in the census would significantly strengthen the predictive ability of regression models examining determinants of migration, as well as sexspecific differences between migrants.

The analyses conducted in this study provide a rich source of information on female migration across the lifespan that complements subnational migration studies and may have relevance in other low- and middle-income countries. Addressing the measurement and impact of female migration is an issue of importance for researchers, policymakers, and nongovernmental organizations working in the development sector. In order to better meet the varied needs of female migrants of all ages and to plan for changing population distribution within Ghana, we would make the following recommendations:

- Data collection and analyses of female migration cannot afford to exclude migrants outside 15-49 years of age. Female migrants have unique agespecific needs, such as integrating into a new school or ensuring that appropriate support systems exist to assist with challenges brought on by 
ageing. Data is needed on female migrants of all ages, not just those of reproductive or working age.

- While multiple surveys measure migration at the national level, the questions they use infrequently permit comparative analyses across time or across surveys. Standardizing questions on migration would allow for more comprehensive analyses of national trends.

- Survey questions on migration should expand upon basic demographic data to include migrants' underlying motivations, migration experiences, and economic contributions.

- Net out-migration in the Volta Region and northern Ghana (Upper West, Upper East, and Northern Regions) may negatively affect local economies and local development efforts. Policymakers concerned about the impact of this productive female labour loss should consider focused interventions in these rural regions to reduce poverty and develop greater economic opportunities for girls and women.

Ultimately, female migration is a dynamic process with inextricable links to development, affecting factors such as the development of communities, the delivery of social services, and the impact of remittances. Should current trends continue, female migration within Africa will rise, particularly to regions offering economic opportunities. The planning of development programmes requires far better data sources than those currently existing, as well as greater attention to analyses using a gendered lens.

\section{Acknowledgements}

We wish to thank Professor Rob Dorrington (University of Cape Town) for providing technical assistance on fitting the multiexponential model migration curve and Professor Allan G. Hill (University of Southampton) for his comments on an earlier version of this paper. We also thank the London School of Economics and Political Science for funding this research. Working drafts of this paper were presented in September 2017 at the annual conference of the British Society for Population Studies in Liverpool, United Kingdom, and in October 2016 at an international Demography and Gender workshop organized by Le Centre de recherches de l'Institut de Démographie de l'Université Paris 1 in Paris, France. 


\section{References}

Addoquaye Tagoe, C. and Kwankye, S.O. (2009). Returning home and re-integrating as an independent child migrant in Ghana. In: Anarfi, J.K. and Kwankye, S.O. (eds.). Independent migration of children in Ghana. Accra: Sundel Services: 206-247.

Agyei, J. and Ofosu-Mensah Ababio, E. (2009). Historical overview of internal migration in Ghana. In: Anarfi, J.K. and Kwankye, S.O. (eds.). Independent migration of children in Ghana. Accra: Sundel Services: 9-44.

Anarfi, J.K. and Agyei, J. (2009). To move or not to move: The decision-making process of child migrants from northern to southern Ghana. In: Anarfi, J.K. and Kwankye, S.O. (eds.). Independent migration of children in Ghana. Accra: Sundel Services: 101-131.

Anarfi, J.K. and Appiah, M. (2009). The phenomenon of independent child migration in Ghana in the context of a globalised world. In: Anarfi, J.K. and Kwankye, S.O. (eds.). Independent migration of children in Ghana. Accra: Sundel Services: 4570 .

Anarfi, J.K. and Kwankye, S.O. (2009). Independent migration of children in Ghana. Legon: Sundel Services.

Awumbila, M. and Ardayfio-Schandorf, E. (2008). Gendered poverty, migration and livelihood strategies of female porters in Accra, Ghana. Norsk Geografisk Tidsskrift - Norwegian Journal of Geography 62(3): 171-179. doi:10.1080/ 00291950802335772.

Beegle, K. and Poulin, M. (2013). Migration and the transition to adulthood in contemporary Malawi. Annals of the American Academy of Political and Social Science 648(1): 38-51. doi:10.1177/0002716213481329.

Caldwell, J.C. (1969). African rural-urban migration: The movement to Ghana's towns. London: C. Hurst.

Camlin, C.S., Snow, R.C., and Hosegood, V. (2014). Gendered patterns of migration in rural South Africa. Population Space and Place 20(6): 528-551. doi:10.1002/ psp.1794.

Contreras, R. and Griffith, D. (2012). Managing migration, managing motherhood: The moral economy of gendered migration. International Migration 50(4): 51-66. doi:10.1111/j.1468-2435.2012.00771.x. 
Daily Express (September 28, 2010). 'Kayayei' numbers higher than anticipated. Daily Express. http://statsghana.gov.gh/docfiles/news/Kayayei.pdf.

Donato, K.M. and Gabaccia, D. (2015). Gender and international migration. New York: Russell Sage Foundation.

Dorrington, R. (2013). Estimation of migration from census data. In: Moultrie, T., Dorrington, R.E., Hill, A.G., Hill, K., Timæus, I., and Zaba, B. (eds.). Tools for demographic estimation. Paris: IUSSP: 376-389.

Elias, J. (2010). Making migrant domestic work visible: The rights based approach to migration and the 'challenges of social reproduction.' Review of International Political Economy 17(5): 840-859. doi:10.1080/09692290903573872.

Findley, S.E. (1989). Les migrations féminines dans les villes africaines: Une revue de leurs motivations et expériences. In. Antoine, P. and Coulibaly, S. (eds.). $L$ 'insertion urbaine des migrants en Afrique. Paris: ORSTOM: 55-70.

Ford, K. and Hosegood, V. (2005). Aids mortality and the mobility of children in Kwazulu Natal, South Africa. Demography 42(4): 757-768. doi:10.1353/dem. 2005.0029.

Frempong-Ainguah, F., Badasu D.M., and Codjoe, S.N.A. (2009). North-South independent child migration in Ghana: The push and pull factors. In: Anarfi, J.K. and Kwankye, S.O. (eds.). Independent migration of children in Ghana. Accra: Sundel Services: $71-100$.

GSS (1999). Government of Ghana 2000 Population and Housing Census: Enumerator's manual. Accra: Ghana Statistical Service.

GSS (2003). 2000 Population and Housing Census administrative report. Accra: Ghana Statistical Service.

GSS (2012). 2010 Population and Housing Census post enumeration survey report. Accra: Ghana Statistical Service.

GSS (2013a). Children, adolescents and young people. In: 2010 Population and Housing Census. Accra: Ghana Statistical Service.

GSS (2013b). 2010 Population and Housing Census: Regional analytical report: Greater Accra Region. Accra: Ghana Statistical Service.

GSS (2013c). 2010 Population and Housing Census: National analytical report. Accra: Statistical Service. 
GSS (2014). 2010 Population and Housing Census report: Fertility. Accra: Ghana Statistical Service.

GSS, GHS, and DHS Program (2015). Ghana Demographic and Health Survey 2014. Accra: Ghana Statistical Service, Ghana Health Service, and the DHS Program.

GSS, GHS, and ICF Macro (1994). Ghana Demographic and Health Survey 1993. Accra: Ghana Statistical Service, Ghana Health Service, and ICF Macro.

GSS, GHS, and ICF Macro (2009). Ghana Demographic and Health Survey 2008. Calverton: Ghana Statistical Service, Ghana Health Service, and ICF Macro.

GSS and IRD (1989). Ghana Demographic and Health Survey 1988. Accra: Ghana Statistical Service and Institute for Resource Development.

GSS and Macro International (1999). Ghana Demographic and Health Survey 1998. Accra: Ghana Statistical Service and Macro International.

GSS, NMIMR, and ICF Macro (2004). Ghana Demographic and Health Survey 2003. Calverton: Ghana Statistical Service, Noguchi Memorial Institute for Medical Research, and IFC Macro.

Guo, M., Chow, N.W.S., and Palinkas, L.A. (2011). Circular migration and life course of female domestic workers in Beijing. Asian Population Studies 7(1): 51-67. doi:10.1080/17441730.2011.544905.

Hofmann, E.T. and Buckley, C.J. (2012). Cultural responses to changing gender patterns of migration in Georgia. International Migration 50(5): 77-94. doi:10.1111/j.1468-2435.2010.00681.x.

Kearney, H. (November 22, 2013). Ghana's female porters get family planning advice. The Guardian. https://www.theguardian.com/global-development-professionalsnetwork/2013/nov/22/ghanas-female-porters-get-family-planning-advice-casestudies.

Kwankye, S.O. and Addoquaye Tagoe, C. (2009). City life outside the home: The experiences of independent child migrants in Ghana. In: Anarfi, J.K. and Kwankye, S.O. (eds.). Independent migration of children in Ghana. Accra: Sundel Services: $132-170$.

Little, J. and Dorrington, R. (2013). The multi-exponential model migration schedule. In: Moultrie, T., Dorrington, R.E., Hill, A.G., Hill, K., Timæus, I., and Zaba, B. (eds.). Tools for demographic estimation. Paris: IUSSP: 390-402. 
Llácer, A., Zunzunegui, M.V., del Amo, J., Mazarrasa, L., and Bolůmar, F. (2007). The contribution of a gender perspective to the understanding of migrants' health. Journal of Epidemiology and Community Health 61(S2): ii4-ii10. doi:10.1136/ jech.2007.061770.

Moultrie, T., Dorrington, R.E., Hill, A.G., Hill, K., Timæus I.M., and Zaba, B. (2013). Tools for demographic estimation. Paris: IUSSP.

Parliament of the Republic of Ghana (2016). Parliamentary debates: Official report. Accra: Parliament House.

Quartey, P. and Yambilla, E. (2009). The costs and benefits of child migration in Ghana: The case of child migrants from Northern Ghana. In: Anarfi, J.K. and Kwankye, S.O. (eds.). Independent migration of children in Ghana. Accra: Sundel Services: 248-291.

Resurreccion, B.P. (2009). Female migration and social reproduction in the Mekong region. Asian and Pacific Migration Journal 18(1): 101-122. doi:10.1177/ 011719680901800105.

Rogers, A. and Castro, L.J. (1981). Model migration schedules. Laxenburg: International Institute for Applied Systems Analysis.

Spoorenberg, T. (2015). Population estimation: Regional workshop on the production of population estimates and demographic indicators. Addis Ababa: United Nations, Department of Economic and Social Affairs, Population Division.

Thiel, A. and Stasik, M. (2016). Market men and station women: Changing significations of gendered space in Accra, Ghana. Journal of Contemporary African Studies 34(4): 459-478. doi:10.1080/02589001.2017.1281385.

Toma, S. and Vause, S. (2014). Gender differences in the role of migrant networks: Comparing Congolese and Senegalese migration flows. International Migration Review 48(4): 972-997. doi:10.1111/imre.12150.

Tufuor, T., Niehof, A., Sato, C., and van der Horst, H. (2015). Extending the moral economy beyond households: Gendered livelihood strategies of single migrant women in Accra, Ghana. Women's Studies International Forum 50: 20-29. doi:10.1016/j.wsif.2015.02.009.

Twum-Baah, K.A., Nabila, J.S., and Aryee, A.F. (1995). Migration research study in Ghana: Volume 1: Internal migration. Accra: Ghana Statistical Service.

UNDESA (1970). Manual VI: Methods of measuring internal migration. New York: United Nations. 
UNDESA (2014). World urbanization prospects: The 2014 revision, highlights. New York: United Nations.

WHO (2018). Global Health Observatory data repository: Life tables by country: Ghana. Geneva: World Health Organization.

Yeboah, I., Dodoo, F., Kwankye, S., Nyarko, P., Badasu, D., and Biavaschi, C. (2010). Development on the move: Measuring and optimising migration's economic and social impacts. Legon: Regional Institute for Population Studies (RIPS) at the University of Ghana and Miami University.

Zlotnik, H. (1995). Migration and the family: the female perspective. Asian and Pacific Migration Journal 4(2-3): 253-271. doi:10.1177/011719689500400205. 


\section{Appendix 1: Demographic methods}

This technical appendix justifies the methods we used to analyse female migration. It also details the assumptions, applications, and limitations of these methods.

\section{A-1.1 Rogers-Castro multiexponential model migration schedule}

Following the instructions detailed in Tools for Demographic Estimation, we fitted a Rogers-Castro multiexponential model migration schedule to observed migration data in order to represent typical age patterns of migration (Rogers and Castro 1981; Little and Dorrington 2013). These migration schedules range from 7 to 13 parameters, depending on the model's complexity, and depict the dependency between age and migration (Little and Dorrington 2013). Checking the "shape" or age distribution of migrant flows by fitting a model migration schedule also permitted us to check our estimates of net internal female migration in Section A-3.

Before applying this method, we obtained migration rates for single ages, examined the population's age structure, and examined the relative completeness of the census counts. We assumed that (1) the census accurately counted the population by subnational region and place of birth and (2) the census identified people who moved from one region to another in the time period of interest (1995-2000).

The first step in applying this method is to prepare a schedule of the observed rates. We used census data that gave the numbers of migrants who survived the fiveyear migration interval 1995-2000. From this data, it is possible to calculate one-year age propensities by backcasting census respondents to the region where they reported living in 1995. The age-specific out-migration propensity is calculated for each oneyear age group as the ratio of migrants to the number at risk of migrating over the time period (Little and Dorrington 2013).

The second step is to decide which multiexponential model best fits the data. As noted earlier (Section 4.2, Demographic structure of internal migrants), since retirement is not concentrated among specific ages in this data and the data may exaggerate older ages (Little and Dorrington 2013), we adopted the standard 7-parameter model rather than the more complex 9-, 11-, or 13-parameter models.

For the third step, fitting the model using Solver, we obtained an Excel Workbook for fitting model migration schedules directly from Professor Rob Dorrington at the University of Cape Town. Our calculations for fitting this model appear in a multipage Excel Workbook that is available upon request.

Then, in step four, we evaluated the model's fit using the mean absolute percentage error statistic. At $7 \%$ for both sexes, it is within the boundaries for achieving 
a reasonable fit. We also calculated the R-squared values for males (92\%) and females (89\%). Both values are acceptable compared to the established threshold of $90 \%$, indicating that the models reasonably fit the data (Little and Dorrington 2013). Tstatistics are significant at the 0.05 level for all coefficients. We also checked that the age-specific migration rates were visually compatible with the Rogers-Castro model and looked for extreme values that could distort the parameters in our model.

Since we employed census data for these models, they experience the limitations of census data detailed in our article (Section 5, Discussion). Furthermore, a limitation of this method is that without accurate, well-behaved data, it is possible that the model may be overparameterized if it does not produce a close fit (Little and Dorrington 2013). Since the lowest-parameter model best fitted the data, we are not concerned about overparameterization.

\section{A-1.2 Logistic regression analyses}

To examine the effects of demographic indicators on the likelihood of a girl or woman migrating internally in 2000 and 2010, we conducted logistic regression analyses using SPSS Statistics 22.0 software. Binary logistic regression modelled the effects of selected independent variables on whether or not a girl or woman was identified in the census as ever having migrated internally (see Table 2 for criteria used to classify migrants). International migrants were excluded. Selection of the independent variables was based on a literature review of push- and pull-factors of migration. We examined the following independent variables: age (in one-year and five-year age groups), education status (ever attended or attending school), marital status, religion, ethnicity, residence (urban, rural), work status (worked for pay, profit, or family gain; did not work), and relationship to household head.

These analyses assume that the census correctly identifies all girls and women who have migrated within Ghana and that our dependent variable (ever having migrated internally) can be measured on a dichotomous scale (yes/no). We know, however, that the census questionnaires' understanding and measuring of migration do not capture contemporary migration patterns identified via other sources of migration data. Most movements between place of birth and current residence are missing, leading to a likely undercount of internal migrants. Improving the census's ability to capture contemporary migration patterns (e.g., cyclical migration, seasonal migration) would significantly strengthen the predictive ability of this regression model. 


\section{A-1.3 Estimates of net internal female migration from place of birth data}

To generate estimates of net internal female migration from census data, we followed the instructions detailed in Tools for Demographic Estimation for estimating subnational regional net in- and out-migration from place of birth data (Dorrington 2013). This estimation required the number of females, in five-year age groups, by subnational region in 2010 and by subnational region at the preceding census in 2000 . For estimating deaths in this period, we calculated survival factors using model life tables from GSS (GSS 2013c).

Our assumptions are as follows:

1. Ghana's censuses correctly identify region of birth and accurately count the population by subnational region.

2. We can accurately estimate the mortality of people moving between two regions in Ghana.

Before applying the method, Dorrington (2013) warns demographers to examine the data's age structure of the population and the data's relative completeness. As noted in our article (Section 3.1, Data), we assessed data quality and completeness by (1) reviewing the post-enumeration surveys conducted to assess coverage and content errors (GSS 2003, 2012) and (2) comparing key variables between the microdata and censuses. The microdata sample from the 2010 Census more accurately reflects the complete census than the microdata sample from 2000 in which the age structure differs slightly (Table 1). Unfortunately, the 2000 Census's post-enumeration survey data is physically missing, preventing analysis of whether or not the final census results required adjustment. The 2010 Census required no adjustments based on the low net coverage error of $1.8 \%$ at the national level (GSS 2012). While this data is imperfect, it is the best currently available for estimating net internal migration in Ghana.

Dorrington (2013) also warns demographers that the estimations are sensitive to census quality: for example, inaccurately recorded place of birth (e.g., respondent may be unaware of boundary changes or may be unaware of person's place of birth), inability to completely identify all migrants and from where they migrated (i.e., undercount), and net migration's underestimation of migrant flows into and out of a region.

The first step in estimating net internal migration between subnational regions from place of birth data is to decide on survival factors. While we considered survival factors generated by the 2005 life table for Ghana from the World Health Organization's (WHO) Global Health Observatory data repository (WHO 2018) (Table A-1), we ultimately used survival factors derived from the Urban Females and Rural Females model life tables produced by the Ghana Statistical Service (GSS) (2013c). 
Since we had reason to believe that mortality differed between regions, using the Urban Females and Rural Females life tables produced by the GSS permitted us to better match the mortality profiles of each region. Ten-year survival factors determined by the Urban Females model life table were used to generate migration estimates for the Greater Accra (see " ${ }_{5} \mathrm{~S}_{x+10}$ " in the fifth column of Table A-2) and Ashanti Regions, where the majority of girls and women reside in urban areas $(90.5 \%$ and $59.6 \%$ respectively) (Figure 1). We used the GSS's Rural Females model life table to generate ten-year survival factors used in the estimates for the other eight regions, where the rural population exceeded the urban population (see " ${ }_{5} \mathrm{~S}_{x+10}$ " in the fifth column of Table A-3). The second step is to use these survival factors to estimate the number of deaths that occurred between the 2000 and 2010 Censuses. The third step is to estimate the net number of in-migrants or out-migrants.

\section{Table A-1: Comparison of overall net migration estimates based on changes to survival factors}

\begin{tabular}{lccc}
\hline Region & $\begin{array}{l}\text { Overall net migration } \\
\text { As estimated with constant survival } \\
\text { factors for all regions, based on the } \\
\text { WHO 2005 life table for Ghana }\end{array}$ & $\begin{array}{l}\text { As estimated with separate survival } \\
\text { factors for predominately rural or urban } \\
\text { regions, based on Ghana's 2010 Census } \\
\text { life tables }\end{array}$ & \% difference \\
\hline Western & $-13,332$ & $-13,711$ & -1.40 \\
Central & $-18,117$ & $-16,121$ & 5.83 \\
Greater Accra & 318,278 & 300,213 & 2.92 \\
Volta & $-105,237$ & $-101,561$ & 1.78 \\
Eastern & $-74,510$ & $-71,130$ & 2.32 \\
Ashanti & 106,929 & 101,431 & 2.64 \\
Brong Ahafo & $-12,627$ & $-14,939$ & -8.39 \\
Northern & $-111,108$ & $-109,085$ & 0.92 \\
Upper East & $-47,941$ & $-47,212$ & 0.77 \\
Upper West & $-41,916$ & $-41,734$ & 0.22 \\
\hline
\end{tabular}

Table A-2 works through these steps for estimating the net number of female inmigrants. The second and third columns show the number of girls and women living in the Greater Accra Region who were born outside the region, as counted by the 2000 and 2010 Censuses. We calculated the ten-year survival factors $\left({ }_{5} S_{x+10}\right)$ in the fifth column using data from the GSS (2013c) Urban Females model life table. The seventh column (Do) is the number of estimated deaths of in-migrants who were born outside that occurred in the ten years between censuses $(n)$. We estimated deaths of people born outside the region (denoted by the superscript ${ }^{O}$ ) aged between $x$ and $x+10$ years at the 
time of the first census $(t),{ }_{5} D_{x}^{O}$, of those aged $A-n$ and older at the first census, ${ }_{\infty} D_{A-n}^{O}$, and of those born between the censuses, $D_{B}^{O}$, as follows:

For those born between the two censuses

$$
\begin{aligned}
& D_{B}^{O}=\frac{1}{2}\left({ }_{5} N_{0}^{O}(2010)\right) \times\left(\left(1 / S_{B, 10}\right)-1\right) \\
& =\frac{1}{2}\left(34,950 \times\left(\left(\frac{1}{0.92534}\right)-1\right)\right. \\
& =1,410
\end{aligned}
$$

For those aged 65 years and older at the time of the first census

$$
\begin{aligned}
& { }_{\infty} D_{65}^{O}=\frac{1}{2}\left({ }_{\infty} N_{65}^{O}(2000) \times{ }_{\infty} S_{65,10}+{ }_{\infty} N_{75}^{O}(2010)\right) \times\left(\left(1 /{ }_{\infty} S_{65,10}\right)-1\right) \\
& =\frac{1}{2}((6,630+4,260+9,520) \times 0.62448+14,730) \times\left(\left(\frac{1}{0.62448}\right)-1\right) \\
& =8,261
\end{aligned}
$$

For all other age groups, such as those aged 30-34 years at the time of the first census

$$
\begin{aligned}
& { }_{5} D_{30}^{O}=\frac{1}{2}\left({ }_{5} N_{30}^{O}(2000) \times{ }_{5} S_{30,10}+{ }_{5} N_{40}^{O}(2010)\right) \times\left(\left(1 /{ }_{5} S_{30,10}\right)-1\right) \\
& =\frac{1}{2}(53,230 \times 0.93040+57,480) \times\left(\left(\frac{1}{0.93040}\right)-1\right) \\
& =4,002
\end{aligned}
$$

where ${ }_{5} N_{x}^{O}(t)$ represents the number of people born outside the region (by age group) according to the census at time $t$ who were aged between $\mathrm{x}$ and $\mathrm{x}+10$ years.

The final column (Net M (born out)) shows the net number of female migrants into the Greater Accra Region who were born in regions other than the Greater Accra Region for each five-year age group. From 2000 to 2010, a total of 371,632 girls and women born outside the Greater Accra Region moved to the Greater Accra Region (after excluding those who moved out). 
Table A-2: Estimation of the net number of female in-migrants of those born outside by age group, Greater Accra Region, Ghana, 2000-2010

\begin{tabular}{lcccclrl}
\hline Age & $\mathbf{2 0 0 0}$ & $\mathbf{2 0 1 0}$ & $\mathbf{X}$ & ${ }_{5} \mathbf{S}_{x+10}$ & Age at 2nd census & Do & Net $\mathbf{M}$ (born out) \\
\hline $0-4$ & & & $\mathbf{B}$ & 0.92534 & & & \\
$5-9$ & 30,390 & 34,950 & 0 & 0.98072 & $0-4$ & 1,410 & 36,360 \\
$10-14$ & 48,460 & 40,280 & 5 & 0.98272 & $5-9$ & 1,625 & 11,515 \\
$15-19$ & 63,270 & 60,730 & 10 & 0.97981 & $10-14$ & 890 & 23,160 \\
$20-24$ & 68,690 & 117,250 & 20 & 0.96188 & $20-24$ & 1,675 & 54,945 \\
$25-29$ & 69,260 & 119,690 & 25 & 0.94706 & $25-29$ & 2,576 & 53,576 \\
$30-34$ & 53,230 & 93,920 & 30 & 0.93040 & $30-34$ & 3,170 & 27,830 \\
$35-39$ & 45,660 & 74,330 & 35 & 0.91571 & $35-39$ & 3,910 & 25,010 \\
$40-44$ & 35,430 & 57,480 & 40 & 0.90525 & $40-44$ & 4,002 & 15,822 \\
$45-49$ & 26,190 & 44,490 & 45 & 0.89823 & $45-49$ & 3,972 & 13,032 \\
$50-54$ & 19,130 & 39,350 & 50 & 0.88747 & $50-54$ & 3,738 & 16,898 \\
$55-59$ & 12,360 & 25,560 & 55 & 0.86645 & $55-59$ & 2,781 & 9,211 \\
$60-64$ & 9,170 & 19,100 & 60 & 0.83183 & $60-64$ & 2,287 & 9,027 \\
$65-69$ & 6,630 & 11,640 & $65+$ & 0.62448 & $65-69$ & 1,722 & 4,192 \\
$70-74$ & 4,260 & 10,740 & & & $70-74$ & 1,857 & 5,967 \\
$75+$ & 9,520 & 14,730 & & & $75+$ & 8,261 & 9,211 \\
\hline Total & 538,630 & 844,110 & & & Total & 44,911 & 350,391 \\
\hline
\end{tabular}

Table A-3 works through the steps for estimating the net number of female outmigrants. The second and third columns show the number of girls and women living in regions other than Ghana's Upper East Region who were born in the Upper East Region, as counted by the 2000 and 2010 Censuses. We calculated the survival factors $\left.{ }_{5} S_{x+10}\right)$ in the fifth column using data from the GSS Rural Females model life table (2013c). The seventh column (Di) is the number of estimated deaths of out-migrants who were born inside that occurred in the ten years between censuses. It is calculated in the same manner as the deaths of in-migrants who were born outside the region (Do). The final column (Net M (born in)) shows the net number of female out-migrants of those born in the Upper East Region (i.e., the number of girls and women born in the Upper East Region who moved out, less those who have returned). From 2000 to 2010, a total of 54,966 girls and women born in the Upper East Region moved out of the Upper East Region (after excluding those who moved in). 
Table A-3: Estimation of the net number of female out-migrants of those born inside by age group, Upper East Region, Ghana, 2000-2010

\begin{tabular}{lcccclcr}
\hline Age & $\mathbf{2 0 0 0}$ & $\mathbf{2 0 1 0}$ & $\mathbf{X}$ & ${ }_{5} \mathbf{S}_{\boldsymbol{x}+\mathbf{1 0}}$ & Age at 2nd census & Di & Net M (born in) \\
\hline $\mathbf{0 - 4}$ & 10,900 & 8,030 & 0 & 0.96465 & $0-4$ & 340 & 8,370 \\
$5-9$ & 12,660 & 9,050 & 5 & 0.98064 & $5-9$ & 383 & $-1,467$ \\
$10-14$ & 11,270 & 12,680 & 10 & 0.98033 & $10-14$ & 425 & 445 \\
$15-19$ & 12,240 & 16,370 & 15 & 0.96941 & $15-19$ & 284 & 5,384 \\
$20-24$ & 14,640 & 25,790 & 20 & 0.95095 & $20-24$ & 370 & 13,920 \\
$25-29$ & 14,630 & 23,970 & 25 & 0.93235 & $25-29$ & 565 & 9,895 \\
$30-34$ & 11,390 & 17,340 & 30 & 0.92103 & $30-34$ & 806 & 3,516 \\
$35-39$ & 9,160 & 13,470 & 35 & 0.91866 & $35-39$ & 984 & 3,064 \\
$40-44$ & 5,900 & 9,240 & 40 & 0.91618 & $40-44$ & 846 & 926 \\
$45-49$ & 4,680 & 6,670 & 45 & 0.90422 & $45-49$ & 668 & 1,438 \\
$50-54$ & 3,330 & 5,570 & 50 & 0.86801 & $50-54$ & 502 & 1,392 \\
$55-59$ & 2,160 & 2,560 & 55 & 0.78906 & $55-59$ & 360 & -410 \\
$60-64$ & 2,050 & 2,770 & 60 & 0.66829 & $60-64$ & 430 & 1,040 \\
$65-69$ & 1,300 & 1,880 & $65+$ & 0.32150 & $65-69$ & 479 & 309 \\
$70-74$ & 1,100 & 2,290 & & & $70-74$ & 908 & 1,898 \\
$75+$ & 2,110 & 3,370 & & & $75+$ & 5,086 & 5,246 \\
\hline Total & 119,520 & 161,050 & & & Total & 13,436 & 54,966 \\
\hline & & & & & & &
\end{tabular}

After estimating net female in-migration and out-migration for each of Ghana's ten regions, we combined these estimates into Table 7 of our article. While these estimations are currently the most accurate available based on existing data, they have several limitations. As previously mentioned, the quality of census data affects these estimates. Censuses may not identify all migrants and may suffer from an undercount. Additionally, place of birth data and place of residence data are affected by misreporting if boundaries change between rounds or if respondents are ignorant of the boundaries.

\section{A-1.4 Estimates of net female migration using the cohort component method}

To strengthen confidence in our estimates of net internal female migration from census data (Section A-1.2), we compared these estimates to those generated by the cohort component method (Spoorenberg 2015). This estimation required us to first forward- 
project the female population enumerated in the 2000 Census to 2005, based on estimated levels of age-specific fertility and mortality rates. We then forward-projected the estimated female population in 2005 to compare it with the actual female population enumerated in the 2010 Census. Without accurate vital registration statistics on fertility and mortality during these periods, we relied on estimations. For estimating fertility, we used age-specific fertility rates (ASFRs) for women aged 15-49 years (in five-year age groups) produced by the 2003 Ghana Demographic and Household Survey (GDHS) (GSS, NMIMR, and ICF Macro 2004) and the 2008 GDHS (GSS, GHS, and ICF Macro 2009). We applied the urban ASFRs to the Greater Accra and Ashanti Regions and the rural ASFRs to the eight remaining regions. For estimating deaths in this period, we calculated survival factors using WHO model life tables for Ghana (WHO 2018). For 2000-2005, we used the life table for 2003. For 2005-2010, we used the life table for 2008.

Our assumptions are as follows:

1. Life table survival rates are representative of mortality conditions during the intercensal period, and we can accurately estimate mortality.

2. Fertility rates are representative of fertility during the intercensal period, and we can accurately estimate fertility.

3. Female migrants have the same fertility and mortality levels as the enumerated population.

4. The distribution of net migrants is equal across years during the intercensal period.

5. Differences between our projected population in 2010 and the population enumerated in the 2010 Census result from migration.

The first step in estimating net migration using this method was to forward-project the females enumerated in the 2000 Census five years to 2005 (Table A-4). Next, we estimated the total number of surviving female births from 2000 to 2005 (Table A-5). Then, we repeated the process by forward-projecting the projected female population in 2005 to 2010 and estimating surviving female births from 2005 to 2010. Finally, we compared our estimated female population in 2010 to the actual enumerated female population in 2010. Differences between these figures imply in-migration or outmigration.

Table A-4 works through the steps for forward-projecting the female population in the projection intervals. The first column after age group shows the female population (in five-year age groups) residing in the Upper East Region, as counted by the 2000 Census. The next column lists the five-year survival factors that we derived from the WHO life table for Ghana in 2003. The product of these two columns is the projected 
population in 2005; however, there is one exception. The projected population for the age group 0-4 years comes from Table A-5, in which we estimated female births surviving the projection interval 2000-2005. We repeat these steps once more to project the 2005 population forward to 2010 . Finally, we estimate net female migration by subtracting the projected population in 2010 from the population enumerated in the 2010 Census. From 2000 to 2010, the Upper East Region experienced negative net migration, with a total of 75,346 girls and women moving out of the region.

\section{Table A-4: Estimating net intercensal female migration by age (birth) cohorts, according to the cohort component method, in the Upper East Region, Ghana, 2000-2010}

\begin{tabular}{|c|c|c|c|c|c|c|c|}
\hline $\begin{array}{l}\text { Age group } \\
\text { (in years) }\end{array}$ & $\begin{array}{l}\text { Population, } \\
2000 \text { Census } \\
\text { (1) }\end{array}$ & $\begin{array}{l}\text { Five-year life } \\
\text { table survival } \\
\text { ratio } \\
\text { (2) }\end{array}$ & $\begin{array}{l}\text { Projected } \\
\text { population, } \\
2005 \\
(3)=(1) \times(2)\end{array}$ & $\begin{array}{l}\text { Five-year life } \\
\text { table survival } \\
\text { ratio } \\
\text { (4) }\end{array}$ & $\begin{array}{l}\text { Projected } \\
\text { population, } 2010 \\
\qquad(5)=(3) \times(4)\end{array}$ & $\begin{array}{l}\text { Population, } \\
2010 \text { Census } \\
\text { (6) }\end{array}$ & $\begin{array}{l}\text { Estimated net } \\
\text { migrants } \\
(7)=(6)-(5)\end{array}$ \\
\hline $0-4$ & 66,440 & 0.93043 & 85,338 & 0.93923 & 96,152 & 68,450 & $-27,702$ \\
\hline $5-9$ & 75,250 & 0.97342 & 61,818 & 0.97818 & 80,152 & 73,600 & $-6,552$ \\
\hline $10-14$ & 51,260 & 0.98795 & 73,250 & 0.99020 & 60,469 & 64,850 & 4,381 \\
\hline $15-19$ & 40,840 & 0.99121 & 50,643 & 0.99181 & 72,532 & 54,020 & $-18,512$ \\
\hline $20-24$ & 33,840 & 0.98779 & 40,481 & 0.98901 & 50,228 & 42,050 & $-8,178$ \\
\hline $25-29$ & 35,770 & 0.97855 & 33,427 & 0.98357 & 40,036 & 37,640 & $-2,396$ \\
\hline $30-34$ & 29,190 & 0.96822 & 35,003 & 0.97475 & 32,878 & 32,840 & -38 \\
\hline $35-39$ & 26,830 & 0.96136 & 28,262 & 0.96519 & 34,119 & 29,180 & $-4,939$ \\
\hline $40-44$ & 23,800 & 0.95851 & 25,793 & 0.96027 & 27,278 & 26,570 & -708 \\
\hline $45-49$ & 21,870 & 0.95902 & 22,813 & 0.96067 & 24,769 & 20,340 & $-4,429$ \\
\hline $50-54$ & 18,020 & 0.95498 & 20,974 & 0.95746 & 21,915 & 19,450 & $-2,465$ \\
\hline $55-59$ & 11,990 & 0.94552 & 17,209 & 0.94846 & 20,081 & 11,510 & $-8,571$ \\
\hline $60-64$ & 13,240 & 0.91340 & 11,337 & 0.92161 & 16,322 & 14,580 & $-1,742$ \\
\hline $65-69$ & 8,980 & 0.85251 & 12,093 & 0.86934 & 10,448 & 9,350 & $-1,098$ \\
\hline $70+$ & 19,670 & 0.61137 & 19,681 & 0.62723 & 22,858 & 30,460 & 7,602 \\
\hline Total & 476,990 & & 538,121 & & 610,236 & 534,890 & $-75,346$ \\
\hline
\end{tabular}

Notes: Figures in bold were produced using the estimation method for female births surviving the projection interval, as shown in Table A-1.5.

Table A-5 works through the steps for estimating female births surviving the projection intervals. The first column shows the female population aged 15-49 years (in five-year age groups) residing in the Upper East Region, as counted by the 2000 Census. The second column shows the projected female population in 2005, based on our calculations in Table A-4. The third column calculates the mid-period female 
population as an average of the sum of the populations in the first and second columns. ASFRs in the fourth column come directly from the 2003 GDHS, in this example, and are those used for rural areas. The final column, estimated births (2000-2005), is the product of the female mid-period population and the ASFRs multiplied by five (years) to account for the period 2000-2005. For the first interval (2000-2005), we used a sex ratio of 105 for both urban and rural areas based on the 2000 Census report (GSS 2003). For the second interval (2005-2010), we used rural (103.1) and urban (101.2) sex ratios from the 2010 Census report on fertility (GSS 2014). We generated newborn five-year survival ratios using the WHO 2003 and 2008 life tables for Ghana (WHO 2018). From 2000 to 2005, we estimated 85,338 surviving female births in the Upper East Region. This figure goes into the first row (age group 0-4 years) of the fourth column (Projected population, 2005) in Table A-4.

Table A-5: Estimation of female births surviving the projection interval, Upper East Region, Ghana, 2000-2005

\begin{tabular}{|c|c|c|c|c|c|}
\hline \multirow{2}{*}{$\begin{array}{l}\text { Age group } \\
\text { (in years) }\end{array}$} & $\begin{array}{l}\text { Female population, } \\
2000 \text { census }\end{array}$ & $\begin{array}{l}\text { Female population, } \\
2005 \text { projected }\end{array}$ & $\begin{array}{l}\text { Female population, } \\
\text { mid-period }\end{array}$ & $\begin{array}{l}\text { Age-specific } \\
\text { fertility rates }\end{array}$ & $\begin{array}{l}\text { Estimated births } \\
(2000-2005)\end{array}$ \\
\hline & (1) & (2) & $(3)=((1)+(2)) / 2$ & (4) & $(5)=5 \times((3) \times(4))$ \\
\hline $15-19$ & 40,840 & 50,643 & 45,741 & 0.113 & 25,844 \\
\hline $20-24$ & 33,840 & 40,481 & 37,161 & 0.225 & 41,806 \\
\hline $25-29$ & 35,770 & 33,427 & 34,598 & 0.256 & 44,286 \\
\hline $30-34$ & 29,190 & 35,003 & 32,096 & 0.213 & 34,183 \\
\hline 35-39 & 26,830 & 28,262 & 27,546 & 0.179 & 24,654 \\
\hline 40-44 & 23,800 & 25,793 & 24,797 & 0.095 & 11,778 \\
\hline $45-49$ & 21,870 & 22,813 & 22,341 & 0.049 & 5,474 \\
\hline \multicolumn{5}{|l|}{ Total births } & 188,024 \\
\hline \multicolumn{5}{|c|}{ Proportion of female births (sex ratio, rural $=105$ ) } & 0.488 \\
\hline \multicolumn{5}{|c|}{ Total female births (2000-2005) } & 91,719 \\
\hline \multicolumn{5}{|c|}{ Average five-year survival ratio of newborns } & 0.930 \\
\hline \multicolumn{5}{|c|}{ Expected deaths among female births (2000-2005) } & 6,381 \\
\hline \multicolumn{5}{|c|}{ Total surviving female births } & 85,338 \\
\hline
\end{tabular}

The estimates produced using the cohort component method have several limitations beyond the quality of census data. This method is incredibly sensitive to our estimated fertility and mortality rates. Using ASFRs from the GDHS and censuses produced drastically different estimates (Table A-6). ASFRs from the GDHS produced overall net out-migration in six of Ghana's ten regions, whereas ASFRs from the censuses produced overall net out-migration in only two of Ghana's ten regions. Since 
measures between the 2008 GDHS and 2010 Census indicate misreporting of births in the census and census fertility data of questionable reliability, we felt the GDHS ASFRs produced more robust estimates. The mortality rates illustrated less significant swings in the estimates produced using the cohort component method, depending on where we generated the survival rates from. For this reason, we consider our estimations of subnational regional net in- and out-migration from place of birth data (Section A-1.3) to be more robust, as they are affected only by mortality estimates.

\section{Table A-6: Comparison of estimates of net female migration in Ghana produced using different methods}

\begin{tabular}{|c|c|c|c|c|}
\hline \multirow[b]{2}{*}{ Region } & \multicolumn{4}{|c|}{ Overall net female migration } \\
\hline & $\begin{array}{l}\text { As estimated with the } \\
\text { cohort component } \\
\text { method using ASFRs } \\
\text { from the } 2000 \text { and } 2010 \\
\text { Censuses }\end{array}$ & $\begin{array}{l}\text { As estimated with the } \\
\text { cohort component method } \\
\text { using urban/rural ASFRs } \\
\text { from the } 2003 \text { and } 2008 \\
\text { GDHS }\end{array}$ & $\begin{array}{l}\text { As estimated with the } \\
\text { cohort component method } \\
\text { using ASFRs from the } 2003 \\
\text { and } 2008 \text { GDHS with } \\
\text { additional modifications* }\end{array}$ & $\begin{array}{l}\text { As estimated with place } \\
\text { of birth data (Section } \\
\text { A-1.3) }\end{array}$ \\
\hline Western & 332 & $-80,102$ & $-80,102$ & $-13,711$ \\
\hline Central & 118,650 & 51,291 & 33,360 & $-16,121$ \\
\hline Greater Accra & 367,656 & 308,633 & 308,633 & 300,213 \\
\hline Volta & 54,411 & $-13,143$ & $-13,143$ & $-101,561$ \\
\hline Eastern & 27,725 & $-57,576$ & $-57,576$ & $-71,130$ \\
\hline Ashanti & 456,663 & 389,721 & 389,721 & 101,431 \\
\hline Brong Ahafo & 42,939 & $-33,492$ & $-33,492$ & $-14,939$ \\
\hline Northern & 132,650 & 70,086 & $-44,247$ & $-109,085$ \\
\hline Upper East & $-40,570$ & $-75,346$ & $-75,346$ & $-47,212$ \\
\hline Upper West & $-24,367$ & $-47,997$ & $-47,997$ & $-41,734$ \\
\hline
\end{tabular}

Notes: * Women in the Northern Region have the highest total fertility rate (TFR) in Ghana, with 7 children per woman in 2003 and 6.8 children per woman in 2008 (GSS, NMIMR, and ICF Macro 2004, GSS, GHS, and ICF Macro 2009). The Central Region also experiences above average fertility with TFRs of 5 children per woman in 2003 and 5.4 children per woman in 2008 (GSS, NMIMR, and ICF Macro 2004, GSS, GHS, and ICF Macro 2009). To improve the accuracy of our migration estimates using the cohort component method, we adjusted the ASFR upwards when estimating births in these two regions. For estimating births from 2005 to 2010, we multiplied the rural ASFRs by a factor of 1.39 for the Northern Region and a factor of 1.1 for the Central Region. These factors are the ratio of each region's TFR to Ghana's overall rural TFR of 4.9. For estimating births from 2000 to 2005 , we adjusted the Northern Region's ASFRs upward using a factor of 1.25 . 


\section{Appendix 2: Supplementary tables}

\section{Table A-7: Migrants identified by Ghana census questions on migration, 2000 and 2010 (10\% microdata)}

\begin{tabular}{|c|c|c|c|}
\hline 2000 Census questions & $\begin{array}{l}\text { Migrants identified in } 2000 \text { (\%), } \\
\text { by sex }\end{array}$ & 2010 Census questions & $\begin{array}{l}\text { Migrants identified in } 2010 \text { (\%), } \\
\text { by sex }\end{array}$ \\
\hline \multirow{6}{*}{$\begin{array}{l}\text { P06a BORN IN THIS } \\
\text { TOWN/VILLAGE: Was } \\
\text { (NAME) born in this town } \\
\text { or village? If YES go to } \\
\text { P07. } \\
\text { [Note: Only asked of } \\
\text { respondents who were } \\
\text { Ghanaian by birth.] }\end{array}$} & 335,951 of 955,504 females $(35.2 \%)$ & \multirow{6}{*}{$\begin{array}{l}\text { P05 BIRTHPLACE: Was } \\
\text { (NAME) born in this } \\
\text { town/village? If Yes, go } \\
\text { to P07. }\end{array}$} & \multirow{6}{*}{$\begin{array}{l}450,071 \text { of } 1,262,598 \text { females }(35.6 \%) \\
412,035 \text { of } 1,203,691 \text { males }(34.2 \%)\end{array}$} \\
\hline & $\begin{array}{l}\text { Ghanaian female migrants }=274,167 \\
(81.6 \%)\end{array}$ & & \\
\hline & $\begin{array}{l}\text { International foreign female migrants } \\
=61,784(18.4 \%)\end{array}$ & & \\
\hline & 349,023 of 935,654 males $(37.3 \%)$ & & \\
\hline & $\begin{array}{l}\text { Ghanaian male migrants }=262,911 \\
(75.3 \%)\end{array}$ & & \\
\hline & $\begin{array}{l}\text { International foreign male migrants = } \\
86,112(24.7 \%)\end{array}$ & & \\
\hline \multirow{6}{*}{$\begin{array}{l}\text { P06b BIRTHPLACE } \\
\text { OUTSIDE THIS } \\
\text { TOWN/VILLAGE: In what } \\
\text { region or country was } \\
\text { (NAME) born? } \\
\text { [Note: Only asked of } \\
\text { respondents who were } \\
\text { Ghanaian by birth.] }\end{array}$} & 274,167 of 274,167 females $(100 \%)$ & \multirow{6}{*}{$\begin{array}{l}\text { P06 BIRTHPLACE: In } \\
\text { what region or country } \\
\text { was (NAME) born? }\end{array}$} & 450,071 of 450,071 females $(100 \%)$ \\
\hline & $\begin{array}{l}\text { Female internal migrants }=265,153 \\
(96.7 \%)\end{array}$ & & $\begin{array}{l}\text { Female internal migrants }=434,948 \\
(96.6 \%)\end{array}$ \\
\hline & $\begin{array}{l}\text { Female (Ghanaian) international } \\
\text { migrants }=9,014(3.3 \%)\end{array}$ & & $\begin{array}{l}\text { Female international migrants }=15,123 \\
(3.4 \%)\end{array}$ \\
\hline & $262,911$ of 262,911 males ( $100 \%)$ & & 412,035 of 412,035 males $(100 \%)$ \\
\hline & $\begin{array}{l}\text { Male internal migrants }=254,048 \\
(96.6 \%)\end{array}$ & & $\begin{array}{l}\text { Male internal migrants }=394,703 \\
(95.8 \%)\end{array}$ \\
\hline & $\begin{array}{l}\text { Male (Ghanaian) international } \\
\text { migrants }=8,863(3.4 \%)\end{array}$ & & $\begin{array}{l}\text { Male international migrants }=17,332 \\
(4.2 \%)\end{array}$ \\
\hline \multirow{6}{*}{$\begin{array}{l}\text { P07 USUAL PLACE OF } \\
\text { RESIDENCE: In what } \\
\text { district is (NAME'S) usual } \\
\text { residence? }\end{array}$} & 28,679 of 955,504 females $(3 \%)$ & \multirow{6}{*}{$\begin{array}{l}\text { P07 LIVING IN THIS } \\
\text { TOWN/VILLAGE: Has } \\
\text { (NAME) been living in } \\
\text { this village or town since } \\
\text { birth? If Yes, go to P09. }\end{array}$} & $478,783$ of $1,262,598$ females ( $37.9 \%)$ \\
\hline & & & 439,930 of $1,203,691$ males $(36.5 \%)$ \\
\hline & $\begin{array}{l}\text { Female international migrants }=350 \\
(1.2 \%)\end{array}$ & & \\
\hline & 29,797 of 935,654 males $(3.2 \%)$ & & \\
\hline & $\begin{array}{l}\text { Male internal migrants }=29,338 \\
(98.5 \%)\end{array}$ & & \\
\hline & $\begin{array}{l}\text { Male international migrants }=459 \\
(1.5 \%)\end{array}$ & & \\
\hline \multirow{13}{*}{$\begin{array}{l}\text { P08 PLACE OF } \\
\text { RESIDENCE FIVE } \\
\text { YEARS AGO IF (NAME) } \\
\text { IS FIVE YEARS OR } \\
\text { OLDER: In what district } \\
\text { was (NAME'S) usual } \\
\text { place of residence five } \\
\text { years ago? }\end{array}$} & 187,027 of 816,989 females $(19.6 \%)$ & \multirow{6}{*}{$\begin{array}{l}\text { P08 NUMBER OF } \\
\text { YEARS LIVED IN THIS } \\
\text { TOWN/VILLAGE: For } \\
\text { how long has (NAME) } \\
\text { been living in this village } \\
\text { or town? }\end{array}$} & 451,686 of $1,262,598$ females $(35.8 \%)$ \\
\hline & $\begin{array}{l}\text { Female internal migrants }=185,228 \\
(99 \%)\end{array}$ & & \multirow[t]{5}{*}{413,681 of $1,203,691$ males $(34.4 \%)$} \\
\hline & Female international migrants $=$ & & \\
\hline & 189,490 of 935,654 males $(20.3 \%)$ & & \\
\hline & $\begin{array}{l}\text { Male internal migrants }=187,194 \\
(98.8 \%)\end{array}$ & & \\
\hline & $\begin{array}{l}\text { Male international migrants }=2,296 \\
(1.2 \%)\end{array}$ & & \\
\hline & $\begin{array}{l}\text { Total number of migrants identified in } \\
2000 \text { microdata, by sex: }\end{array}$ & & $\begin{array}{l}\text { Total number of migrants identified in } \\
2010 \text { microdata, by sex: }\end{array}$ \\
\hline & 359,960 of 955,504 females $(37.7 \%)$ & & $487,376$ of $1,262,598$ females ( $38.6 \%)$ \\
\hline & $\begin{array}{l}\text { Female internal migrants }=297,031 \\
(31.1 \%) \text { of all females }\end{array}$ & & $\begin{array}{l}\text { Female internal migrants }=472,253 \\
(37.4 \%) \text { of all females }\end{array}$ \\
\hline & $\begin{array}{l}\text { Female international migrants }= \\
62,929(6.6 \%) \text { of all females }\end{array}$ & & $\begin{array}{l}\text { Female international migrants }=15,123 \\
(1.2 \%) \text { of all females }\end{array}$ \\
\hline & 371,577 of 935,654 males $(39.7 \%)$ & & 447,485 of $1,203,691$ males $(37.2 \%)$ \\
\hline & $\begin{array}{l}\text { Male internal migrants }=284,269 \\
(30.4 \%) \text { of all males }\end{array}$ & & $\begin{array}{l}\text { Male internal migrants }=430,153 \\
(35.7 \%) \text { of all males }\end{array}$ \\
\hline & $\begin{array}{l}\text { Male international migrants }=87,308 \\
(9.3 \%) \text { of all males }\end{array}$ & & $\begin{array}{l}\text { Male international migrants }=17,332 \\
(1.4 \%) \text { of all males }\end{array}$ \\
\hline
\end{tabular}


Lattof et al.: Contemporary female migration in Ghana: Analyses of the 2000 and 2010 Censuses

Table A-8: Lifetime female in-migrants by region of origin, out-migrants by region of destination, and net lifetime migration streams, Ghana, 2000 and 2010

\begin{tabular}{lcccccc}
\hline $\begin{array}{l}\text { Region of origin and } \\
\text { destination }\end{array}$ & $\begin{array}{l}\text { Lifetime in- } \\
\text { migrants }\end{array}$ & $\begin{array}{l}\text { Lifetime out- } \\
\text { migrants }\end{array}$ & $\begin{array}{l}\text { Net lifetime } \\
\text { migration }\end{array}$ & $\begin{array}{l}\text { 2010 Census } \\
\text { Lifetime in- } \\
\text { migrants }\end{array}$ & $\begin{array}{l}\text { Lifetime out- } \\
\text { migrants }\end{array}$ & $\begin{array}{l}\text { Net lifetime } \\
\text { migration }\end{array}$ \\
\hline Western & 239,600 & 87,570 & 152,030 & 260,940 & 145,370 & 115,570 \\
Central & 93,920 & 239,510 & $-145,590$ & 185,660 & 318,530 & $-132,870$ \\
Greater Accra & 548,090 & 99,020 & 449,070 & 844,110 & 156,690 & 687,420 \\
Volta & 55,310 & 263,130 & $-207,820$ & 73,670 & 343,070 & $-269,400$ \\
Eastern & 157,800 & 276,400 & $-118,600$ & 207,770 & 388,770 & $-181,000$ \\
Ashanti & 275,470 & 221,720 & 53,750 & 432,430 & 302,070 & 130,360 \\
Brong Ahafo & 168,770 & 102,940 & 65,830 & 217,110 & 172,800 & 44,310 \\
Northern & 54,980 & 121,000 & $-66,020$ & 52,900 & 214,690 & $-161,790$ \\
Upper East & 24,390 & 118,540 & $-94,150$ & 30,640 & 161,050 & $-130,410$ \\
Upper West & 18,140 & 106,640 & $-88,500$ & 21,630 & 123,820 & $-102,190$ \\
\hline Total & $1,636,470$ & $1,636,470$ & 0 & $2,326,860$ & $2,326,860$ & 0 \\
\hline
\end{tabular}

Table A-9: Lifetime male in-migrants by region of origin, out-migrants by region of destination, and net lifetime migration streams, Ghana, 2000 and 2010

\begin{tabular}{lcccccc}
\hline $\begin{array}{l}\text { Region of origin and } \\
\text { destination }\end{array}$ & $\begin{array}{l}\text { Lifetime in- } \\
\text { migrants }\end{array}$ & $\begin{array}{l}\text { Lifetime out- } \\
\text { migrants }\end{array}$ & $\begin{array}{l}\text { Net lifetime } \\
\text { migration }\end{array}$ & $\begin{array}{l}\text { 2010 Census } \\
\text { Lifetime in- } \\
\text { migrants }\end{array}$ & $\begin{array}{l}\text { Lifetime out- } \\
\text { migrants }\end{array}$ & $\begin{array}{l}\text { Net lifetime } \\
\text { migration }\end{array}$ \\
\hline Western & 262,520 & 81,550 & 180,970 & 300,660 & 130,280 & 170,380 \\
Central & 92,160 & 234,820 & $-142,660$ & 186,880 & 292,890 & $-106,010$ \\
Greater Accra & 530,700 & 106,930 & 423,770 & 756,850 & 164,430 & 592,420 \\
Volta & 54,470 & 265,580 & $-211,110$ & 71,190 & 340,920 & $-269,730$ \\
Eastern & 156,980 & 270,710 & $-113,730$ & 206,480 & 359,620 & $-153,140$ \\
Ashanti & 296,640 & 222,440 & 74,200 & 418,030 & 313,050 & 104,980 \\
Brong Ahafo & 191,180 & 104,720 & 86,460 & 242,520 & 164,200 & 78,320 \\
Northern & 53,650 & 133,190 & $-79,540$ & 48,160 & 222,990 & $-174,830$ \\
Upper East & 25,040 & 136,250 & $-111,210$ & 31,000 & 167,780 & $-136,780$ \\
Upper West & 15,490 & 122,640 & $-107,150$ & 21,840 & 127,450 & $-105,610$ \\
\hline Total & $1,678,830$ & $1,678,830$ & & $2,283,610$ & $2,283,610$ & 0 \\
\hline
\end{tabular}


Table A-10: Estimates of the net number of female in-migrants of those born outside by age group, Ghana, 2000-2010

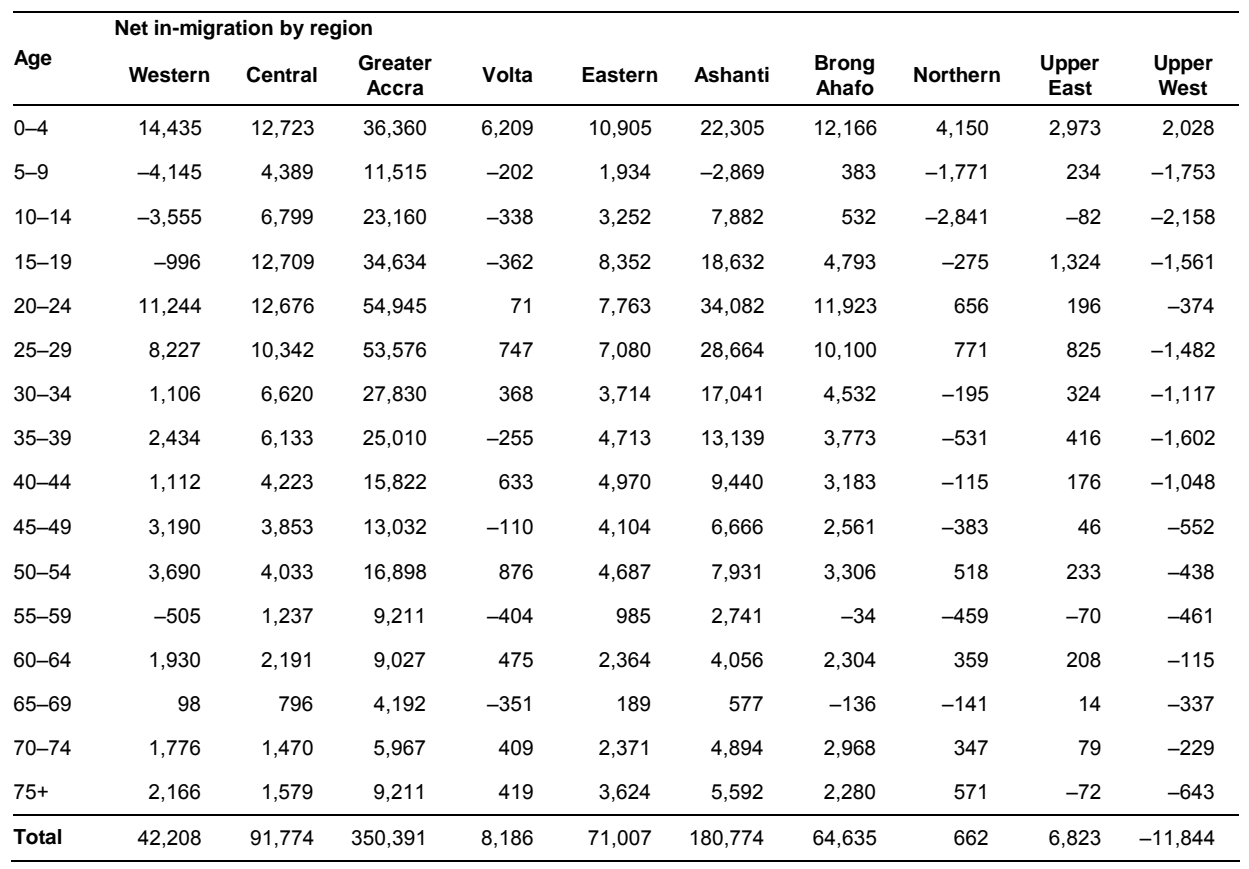


Lattof et al.: Contemporary female migration in Ghana: Analyses of the 2000 and 2010 Censuses

Table A-11: Estimates of the net number of female out-migrants by region of birth and age group, Ghana, 2000-2010

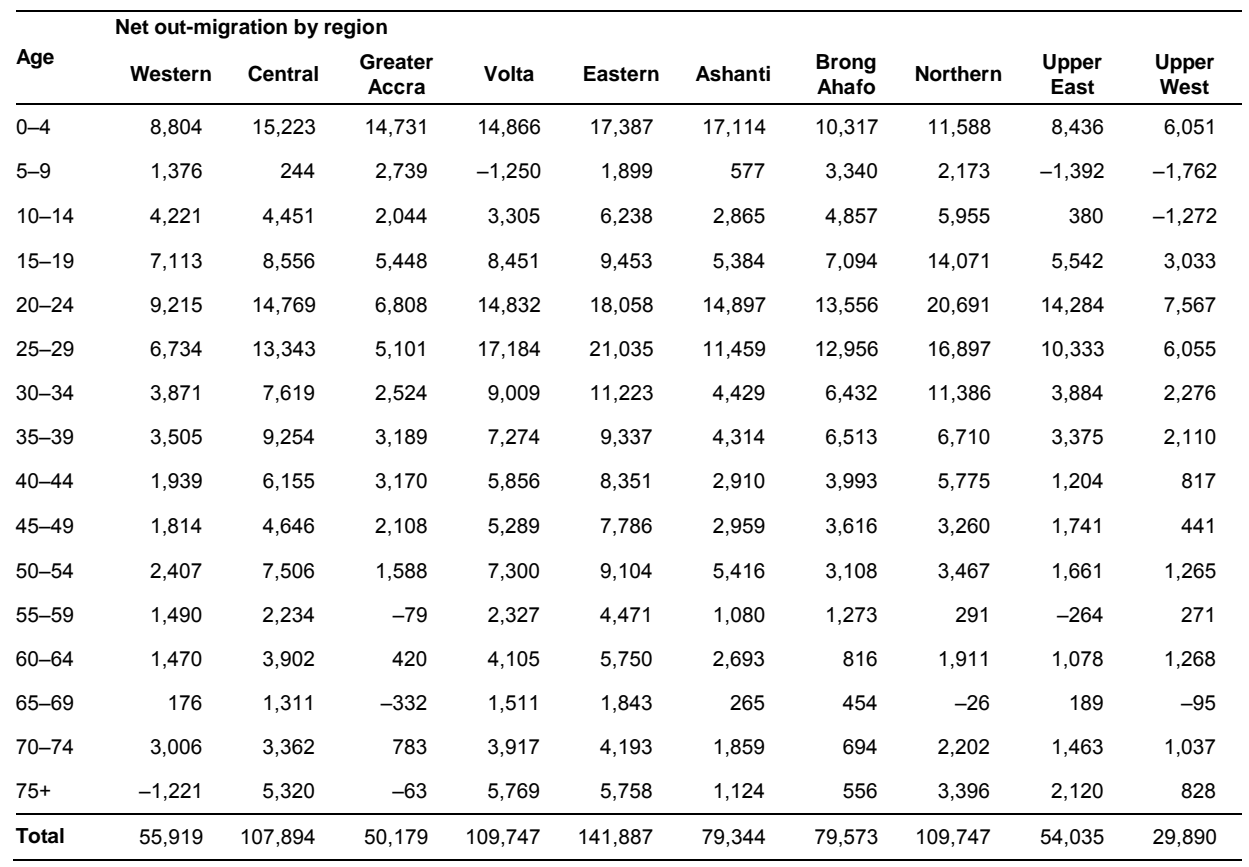

